\title{
Ethnobotanical knowledge among the semi-pastoral Gujjar tribe in the high altitude (Adhwari's) of Churah subdivision, district Chamba, Western Himalaya
}

Dipika Rana, Anupam Bhatt and Brij Lal

\begin{abstract}
Background: The wild plants not only form an integral part of the culture and traditions of the Himalayan tribal communities but also contribute largely to the sustenance of these communities. The tribal people use large varieties of wild fruits, vegetables, fodder, medicinal plants, etc. for meeting their day-to-day requirements. The present study was conducted in Churah subdivision of district Chamba where large populations of Muslim Gujjars inhabit various remote villages. These tribal people are semi-pastoralists, and they seasonally (early summers) migrate to the upper altitudes (Adhwari's) along with their cattle and return to permanent settlements before the onset of winters. A major source of subsistence of these tribal people is on natural resources to a wide extent, and thus, they have wide ethnobotanical knowledge. Therefore, the current study was aimed to report the ethnobotanical knowledge of plants among the Gujjar tribe in Churah subdivision of district Chamba, Himachal Pradesh.

Methods: Extensive field surveys were conducted in 15 remote villages dominant in Gujjar population from June 2016 to September 2017. The Gujjars of the area having ethnobotanical knowledge of the plants were interrogated especially during their stay at the higher altitudes (Adhwari's) through well-structured questionnaires, interviews, and group meetings. The data generated was examined using quantitative tools such as use value, fidelity, and informant consensus factor $\left(F_{\mathrm{ic}}\right)$.

(C) The Author(s). 2019 Open Access This article is distributed under the terms of the Creative Commons Attribution 4.0 International License (http://creativecommons.org/licenses/by/4.0/), which permits unrestricted use, distribution, and reproduction in any medium, provided you give appropriate credit to the original author(s) and the source, provide a link to the Creative Commons license, and indicate if changes were made. The Creative Commons Public Domain Dedication waiver (http://creativecommons.org/publicdomain/zero/1.0/) applies to the data made available in this article, unless otherwise stated. 
(Continued from previous page)

Results: This study reveals 83 plants belonging to 75 genera and 49 families that were observed to have ethnobotanical uses. Plants were listed in five categories as per their use by the Gujjars, i.e. food plants, fruit plants, fodder plants, household, and ethnomedicinal plants. The leaves, fruits, and roots were the most commonly used plant parts in the various preparations. The highest number of plants was recorded from the family Rosaceae followed by Polygonaceae and Betulaceae. On the basis of use value (UV), the most important plants in the study area were Pteridium aquilinum, Juglans regia, Corylus jacquemontii, Urtica dioica, Diplazium maximum, and Angelica glauca. Maximum plant species (32) were reported for ethnomedicinal uses followed by food plants (22 species), household purposes (16 species), edible fruits (15 species), and as fodder plants (14 species). The agreement of the informants conceded the most from the use of various plants used as food plants and fruit plants $\left(F_{\text {ic }}=0.99\right)$, followed by fodder plants and household uses $\left(F_{\mathrm{ic}}=0.98\right)$ while it was least for the use of plants in ethnomedicine $\left(F_{\mathrm{ic}}=0.97\right)$. The fidelity value varied from 8 to $100 \%$ in all the use categories. Phytolacca acinosa (100\%), Stellaria media (100\%), and Urtica dioica (100\%) were among the species with high fidelity level used as food plants, while the important species used as fruit plants in the study area were Berberis lycium (100\%), Prunus armeniaca (100\%), and Rubus ellipticus (100\%). Some important fodder plants with high fidelity values (100\%) were Acer caesium, Aesculus indica, Ailanthus altissima, and Quercus semecarpifolia. The comparison of age interval with the number of plant use revealed the obvious transfer of traditional knowledge among the younger generation, but it was mostly concentrated in the informants within the age group of 60-79 years.

Conclusions: Value addition and product development of wild fruit plants can provide an alternate source of livelihood for the rural people. The identification of the active components of the plants used by the people may provide some useful leads for the development of new drugs which can help in the well-being of mankind. Thus, bioprospection, phytochemical profiling, and evaluation of economically viable products can lead to the optimum harnessing of Himalayan bioresources in this region.

Keywords: Gujjar, Tribe, Adhwari, Himalaya, Informant consensus factor, Use value, Fidelity level

\section{Introduction}

In India, about 54 million tribal people inhabit about 5000 forest-dominated villages that constitute about $15 \%$ of the total geographic area [1]. Traditionally, these tribal groups are known to use a large number of wild plants for various purposes like medicine, food, fodder, fuel, essence, culture, and other miscellaneous purposes [2]. Thus, forests have maintained the very existence of numerous tribes and their culture for centuries, while fulfilling their social, economic, cultural, religious, nutritional, and medical needs [3-8]. Thus, these tribal communities are a rich depository of various ethnobotanical uses of plants and guardians of indigenous traditional knowledge associated with surrounding biological resources which they have used for generations in their day-to-day life $[9,10]$.

Among all the tribal groups, Gujjars are described as the largest pastoral community in India [11]. The tribe is described by varying names as 'Goojar or Gurjara' and is believed to have originated in the times of Huns. The tribe migrated to northern India and settled in various regions of Himachal Pradesh mainly Chamba, Kangra, Una, and Bilaspur [12]. The Muslim Gujjars are known to have first set foot in the princely states of Chamba and Sirmour because of the growing inadequacy of grazing resources in the neighbouring states of Jammu and Kashmir and then gradually migrated to other localities of the state [13]. The Gujjars of Chamba and Kangra are called as the 'Ban Gujjars' as they are nomads/semi-nomads practicing a pastoral lifestyle and comprise primarily of the Muslim population. In Chamba, the total Gujjar population is 9784 out of which $97.12 \%$ are Muslims [14], while Gujjars of Una and Bilaspur are settled Gujjars called the 'Heer Gujjars' and comprise mainly of Hindu population. Despite leading diverse lifestyles, one thing common among all Gujjars is that they all rear large herds of buffaloes.

The semi-nomadic Gujjars have permanent places to stay at the lower elevations, but they temporarily leave for higher altitudes called 'Adhwari's' to graze their cattle mainly comprising buffaloes from mid-May till mid-October. The temporary migration takes along a predetermined set route that is covered in about 2-3 days [15]. The pasture lands are well distributed to the various families of Gujjars through a permit by the forest department of the area, thus also witnessing the proper management of the forest area. The main source of income of the Gujjars is selling of milk and milk products in the local market.

There is no doubt that the various tribal sects like the Gujjars while living in the remote mountain regions depend largely on wild plant resources for sustenance. Their nomadic employment from the ancestry makes them a good knowledge holder as a way of obtaining 
food and finding pasture for livestock that makes them more dependent on the environment [16]. Thus, they have a wide knowledge of use and practices of plant resources which is passed on verbally from one generation to another $[17,18]$. Thereby, documentation of ethnobotanical knowledge is essential for the conservation and utilisation of biological resources [19]. This will also ensure future research on medicinal plant safety and efficacy to validate traditional use and prevent destructive changes in knowledge transmissions between generations [20,21].

Thereby, the present study was undertaken to investigate and document the ethnobotanical knowledge of the Gujjars of Churah region, which they inherit based on the experiences and observations from their ancestors.

\section{Methods}

Study site

The present investigation was undertaken in Churah subdivision of district Chamba of Himachal Pradesh which is located in the Western Himalaya. The district lies between $32^{\circ} 11^{\prime}$ to $33^{\circ} 13^{\prime} \mathrm{N}$ latitude and $75^{\circ} 49^{\prime}$ to $77^{\circ} 3^{\prime} \mathrm{E}$ longitude with an altitudinal range varying between 800 and $5200 \mathrm{~m}$ amsl. Vegetation growth is mainly found in the Ravi basin, which is semi-tropical to Himalayan temperate and sub-Alpine to Alpine types. The maximum Gujjar population in the district consists of Muslims. These are a semi-pastoral tribe, and they seasonally (early summers) migrate to the upper altitudes along with their cattle and return back to permanent settlements before the onset of winters. They celebrate festivals like Eid-ul-Fitr, Id-ul-Zuha, and Shab-I-qader. The social status of these tribal people is generally poor, and they live an isolated life only confined to their own community. The main occupation of the Gujjars is rearing buffaloes, and they sell milk and milk products in the market. In the past, not much in-depth studies pertaining to various ethnobotanical aspects on Gujjar tribal community have been conducted [22, 23].

\section{Data collection}

Rigorous field surveys were conducted in 15 remote villages of Churah subdivision during June 2016 to September 2017 across all seasons to collect maximum information and authenticate the information provided by the local informants during the earlier visits. These villages were shortlisted on the basis of maximum Gujjar populations and thereby were selected for the surveys (Fig. 1). The interviews were conducted both at the permanent settlements and at the higher altitudes (Adhwari's) for which trekking was done. A total of 135 informants within the age group of 11-90 years were interviewed (Fig. 2). The data helped us to analyse the trend of flow of ethnobotanical knowledge between different age classes.
Traditional healers having sound knowledge of ethnomedicinal uses of plants were also interviewed in this study. The information was collected through structured questionnaires, interviews, and group discussions on various ethnobotanical aspects (Additional file 1). Trade-related information about the plants wherever available was also recorded.

Before the initiation of the interviewing process, the consent of the informants was also taken for participation in the study. The Gujjar informants did express some uneasiness in the beginning while sharing information, but gradually they responded quite well. A translator was hired to communicate and translate Gojri into Hindi. Details pertaining to the local name of the plant collected, plant parts used, ethnobotanical use of plants, and method of use were recorded. The informants were also asked to collect and show the plant specimens on site. The complete plant specimens, including its flower or fruit, were collected, dried, and assigned a voucher number (PLP) and then deposited as a record in the herbarium of the institute for future reference. The plant specimens were identified by using Flora of Himachal Pradesh [24]; Flora of Chamba [25]; Flowers of Himalaya [26].

\section{Data analysis}

A comprehensive data analysis was done using different quantitative indices viz. use value, fidelity, and informant consensus factor $\left(F_{\text {ic }}\right)$.

\section{Use value}

The relative importance of the species was calculated using the use value which is a quantitative tool [27]:

$$
\mathrm{UV}=\Sigma U / n
$$

where $U$ is the number of plants cited by each informant for a given species and $n$ is the total number of informants. Use values are high when there are many use reports for a plant signifying its importance, and approach to zero (0) when the use reports are low.

Validation of plant names, family, and plant authority was carried out using the database (http://www.theplantlist.org).

\section{Informant consensus factor}

Informant consensus factor was used to test the agreement on the use of plants in the various categories between the informants. $F_{\text {ic }}$ was calculated using the formula $[28,29]$ :

$$
F_{\text {ic }}=\left(N_{\text {ur }}-N_{\mathrm{t}}\right) /\left(N_{\mathrm{ur}}-1\right)
$$

where $N_{\text {ur }}$ refers to the number of use reports for a particular use/ailment category and $N_{\mathrm{t}}$ is the number of 

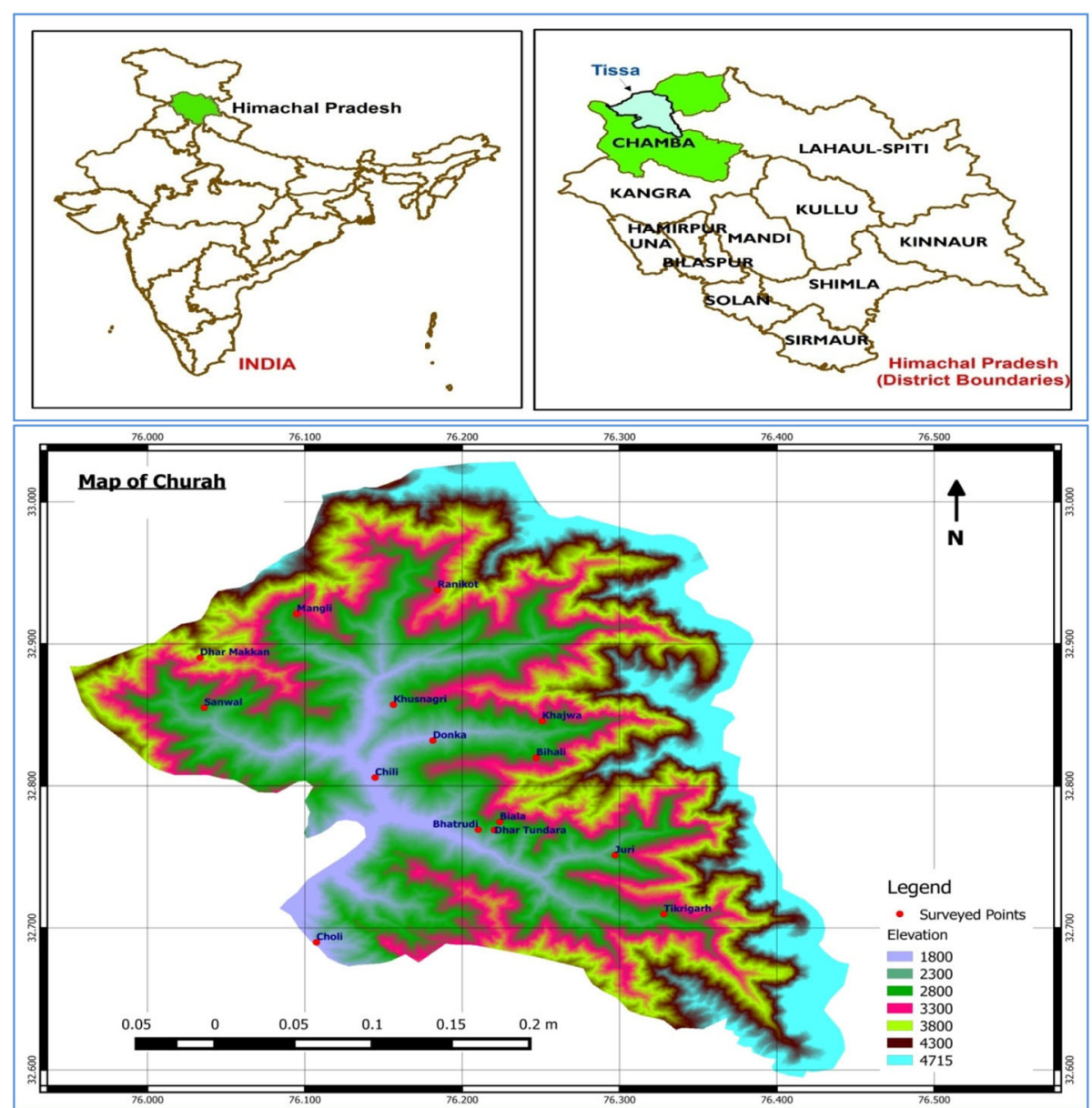

Fig. 1 Map showing the location of surveyed villages

species used for a particular use/ailment category by all informants. The product of this factor ranges from 0 to 1. A high $F_{\text {ic }}$ value (close to 1 ) indicates that relatively few plant species are used by a large proportion of the informants while a low value indicates the disagreement

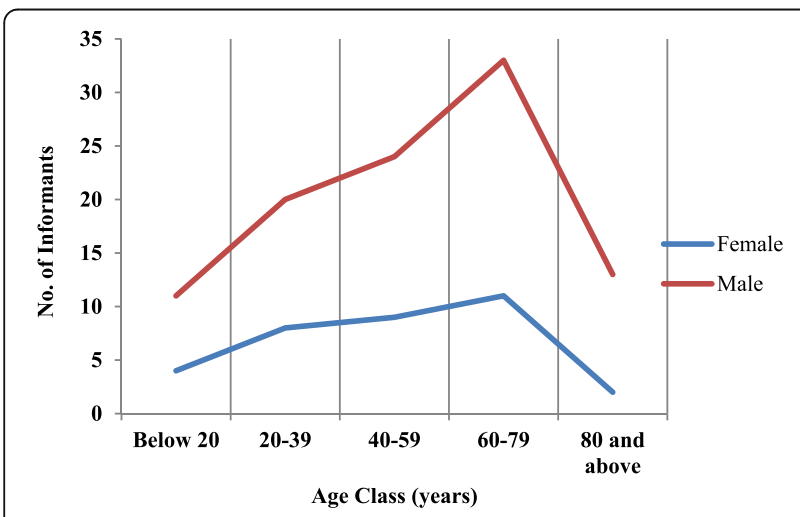

Fig. 2 Demographic description of the informants of the informants on the use of plant species in the different categories [30-32].

\section{Fidelity level (Fl\%)}

It is used to determine the most preferred species in the same use category [33].

$$
\mathrm{Fl}(\%)=\mathrm{Np} / N \times 100
$$

where $\mathrm{Np}$ refers to use reports cited for a given species for a particular category and $N$ is the total number of use reports cited for any given species. High $\mathrm{Fl}$ value (near to 100\%) is observed for plants in which use reports refer to its same way of use, whereas low $\mathrm{Fl}$ values are obtained from plants having multiple different uses $[18,34]$.

\section{Scatter diagram}

A scatter diagram was used to compare the flow of ethnobotanical information among the different age classes of the informants. 


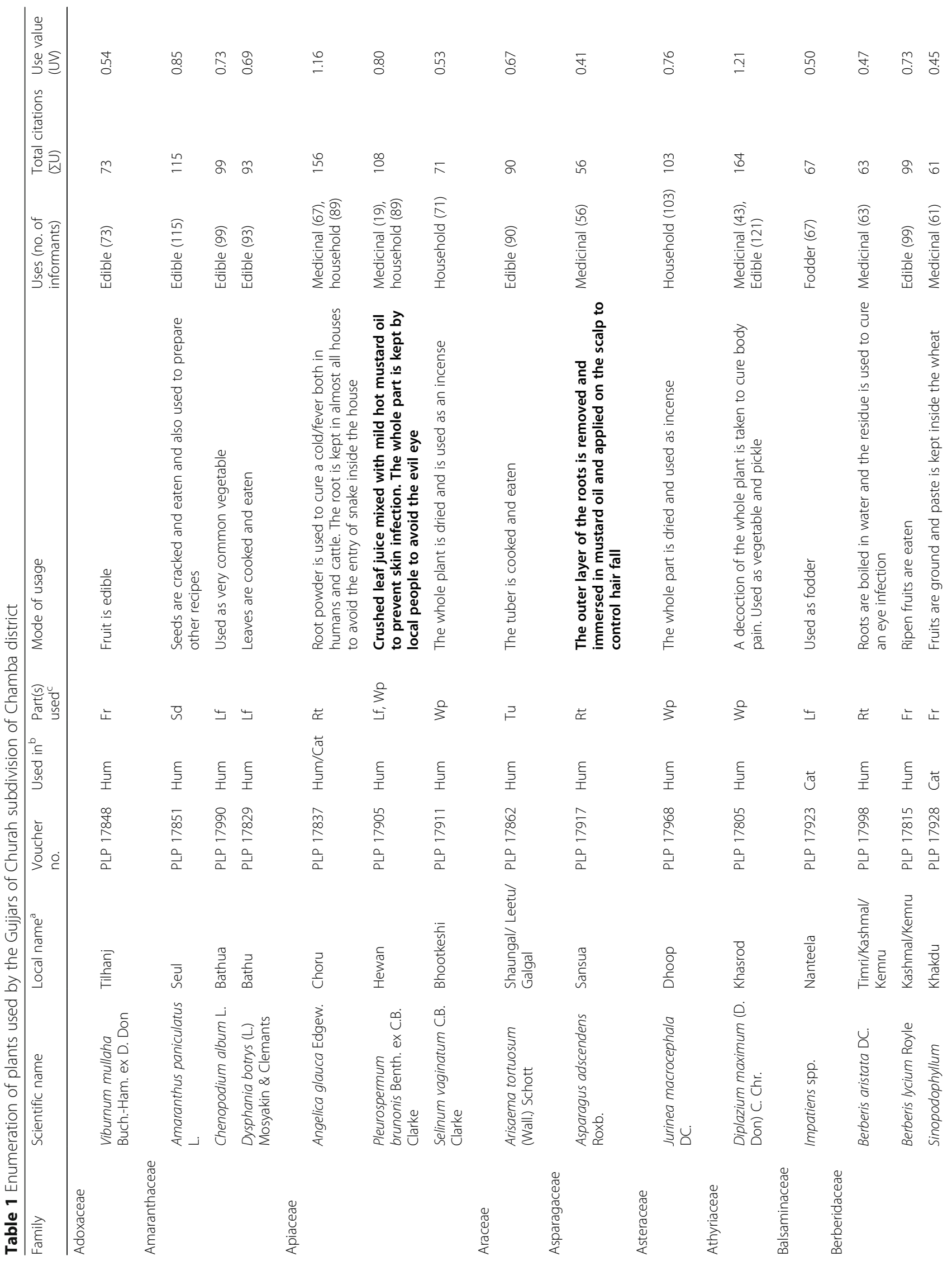




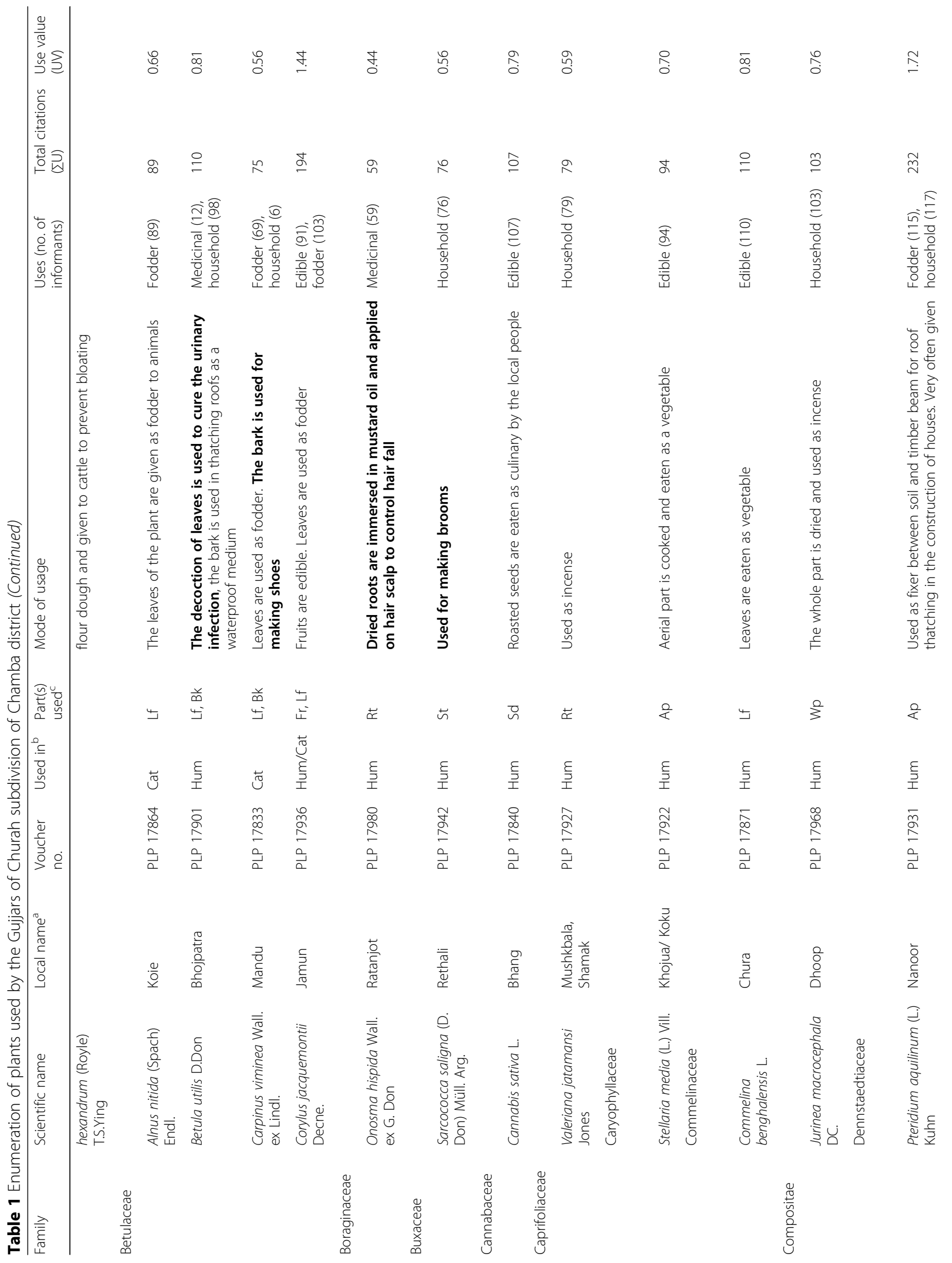




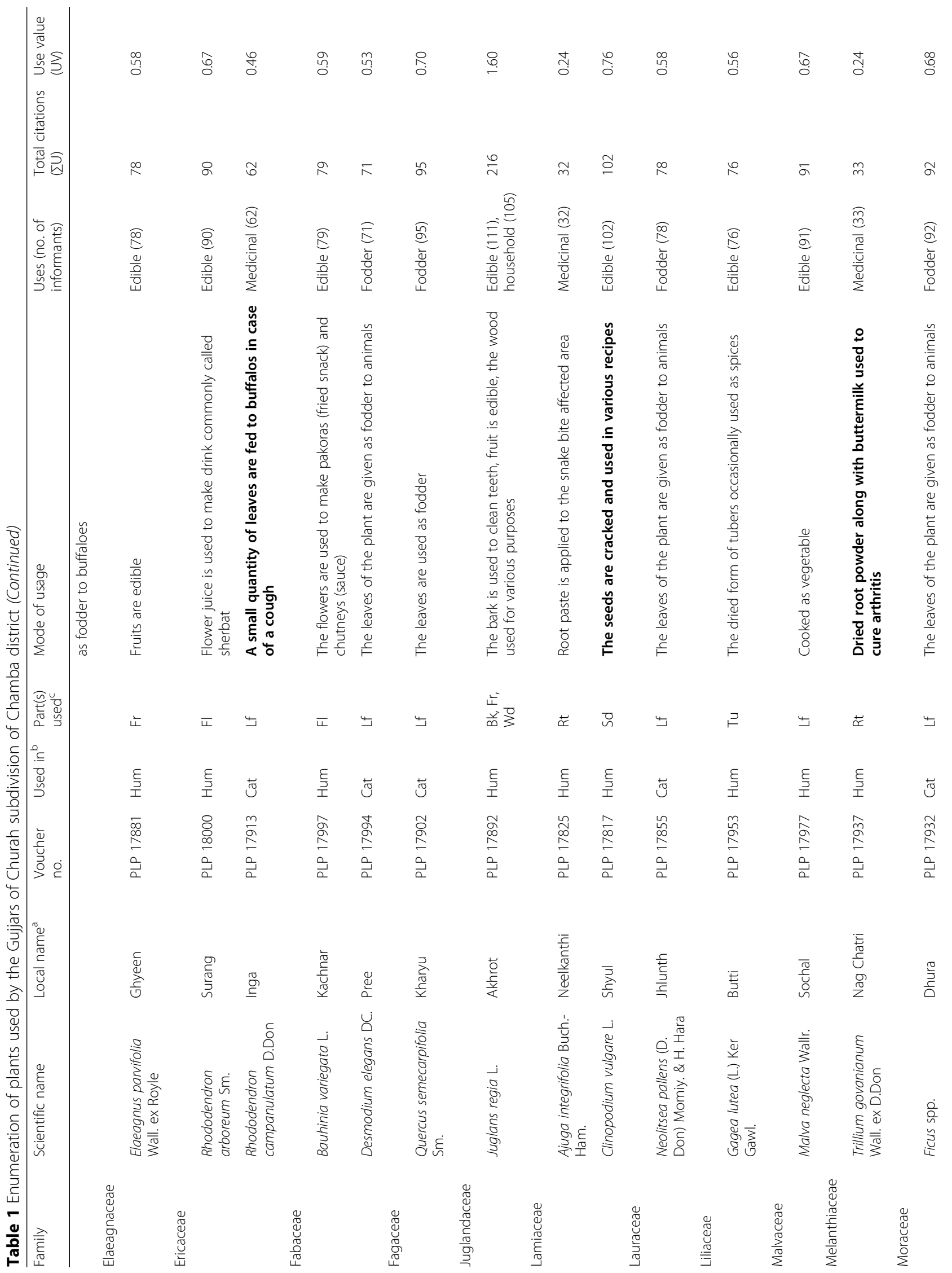




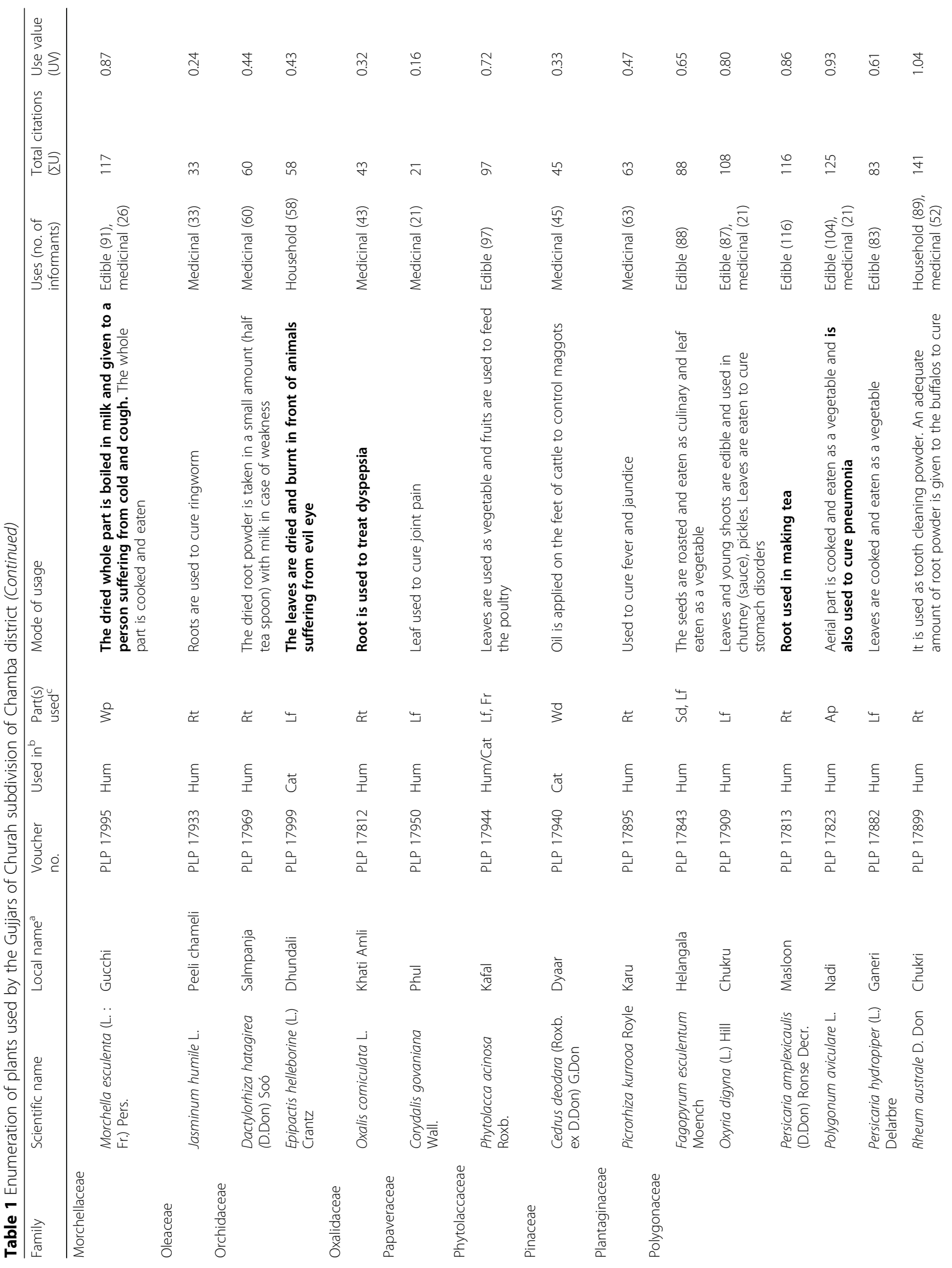




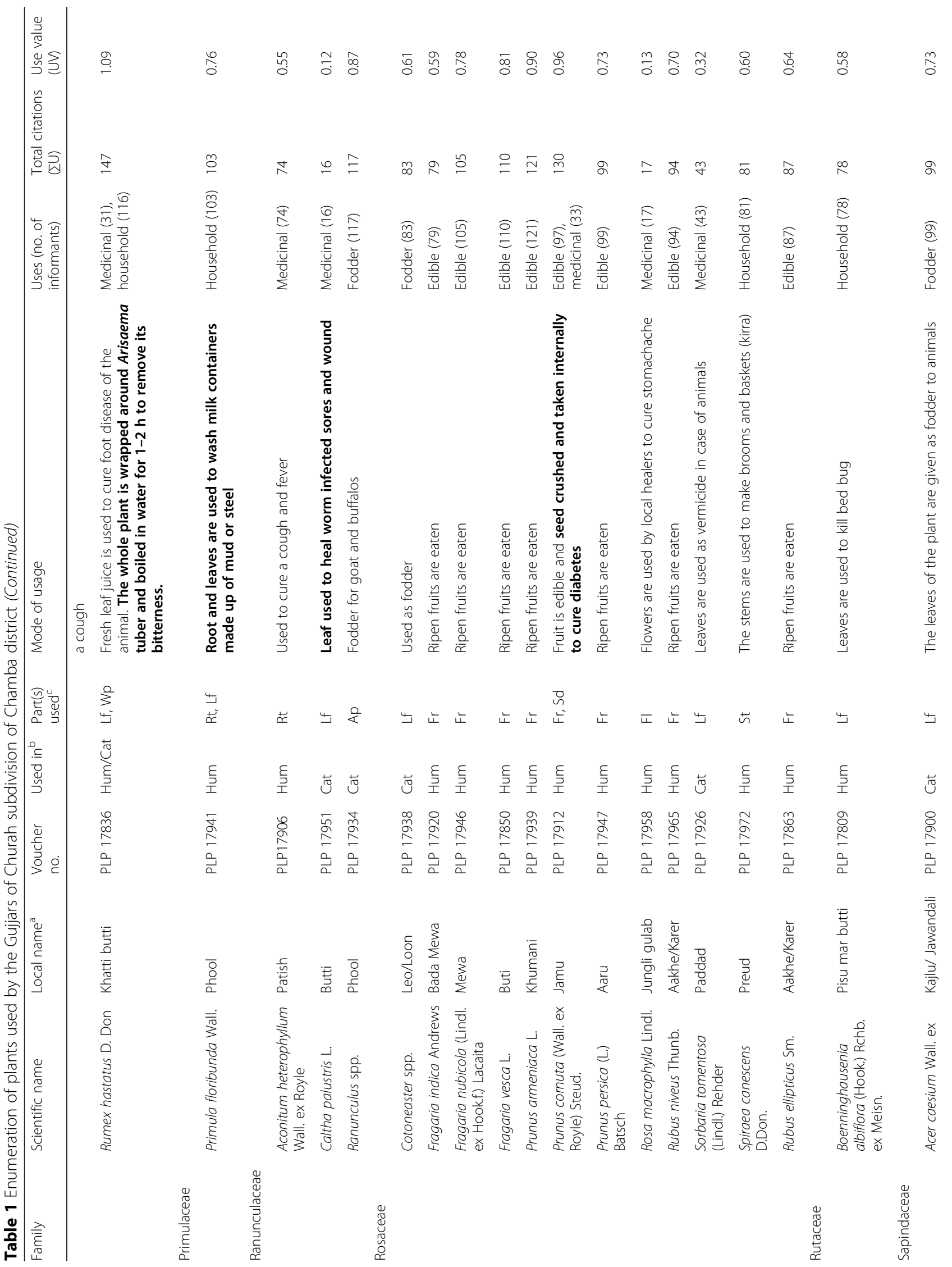


Rana et al. Journal of Ethnobiology and Ethnomedicine $\quad$ (2019) 15:10

Page 10 of 21

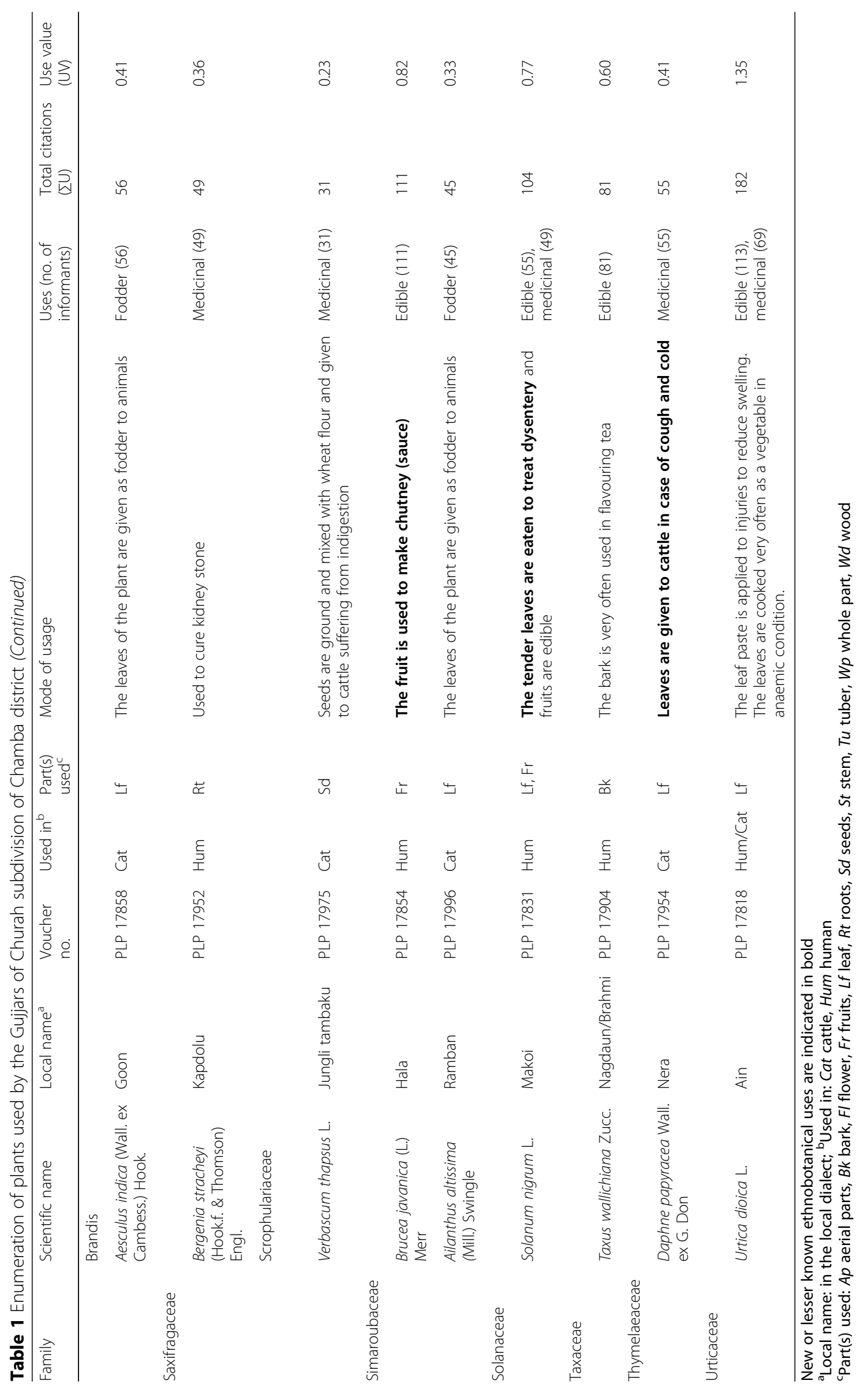




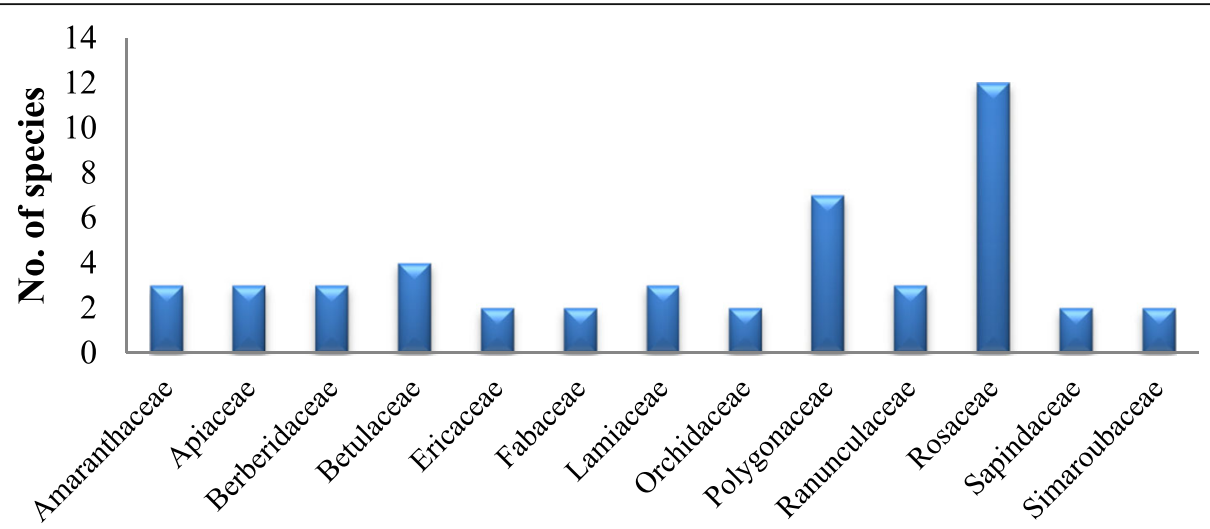

Families

Fig. 3 Dominant families in the study area

\section{Results}

\section{Attributes of the informants}

The characteristics of the informants is given in Fig. 2. Maximum male and female informants who had extensive ethnobotanical knowledge belonged to the age group between 60 and 79 years. The informants below the age of 20 years also responded well depicting the obvious transfer of traditional knowledge among the younger generation (Fig. 2). The children accompany the elders to the higher altitudes and help them in collecting wild plants. They learn about the uses of various plants through observations and especially wild fruits. A similar trend has been shown in the previous studies [4, 35, 36]. The translator helped us in easy communications with the Gujjar informants and even helped in collecting plant specimens from the wild. The female Gujjar informants were more comfortable in providing information to the female researcher as they are quite reticent. The tribal people of the region have a close relationship with nature and the vast experience of resource utilisation [37].

\section{Floristic characteristics of the plants used}

The study area is floristically rich, and the local inhabitants use a large number of plant species for variable uses. A total of 83 plant species belonging to 75 genera and 49 families were recorded in the study area (Table 1 ). The majority of plants belonged to Rosaceae (12 species), Polygonaceae (7 species), Betulaceae (4 species), Amaranthaceae (3 species), Apiaceae (3 species), Berberidaceae (3 species), Lamiaceae (3 species), and Ranunculaceae (3 species) [38-40] (Fig. 3). The genera represented by the highest number of species are Fragaria (3 species), Prunus (3 species), Rubus (2 species), Persicaria (2 species), Rhododendron (2 species), and Berberis (2 species).

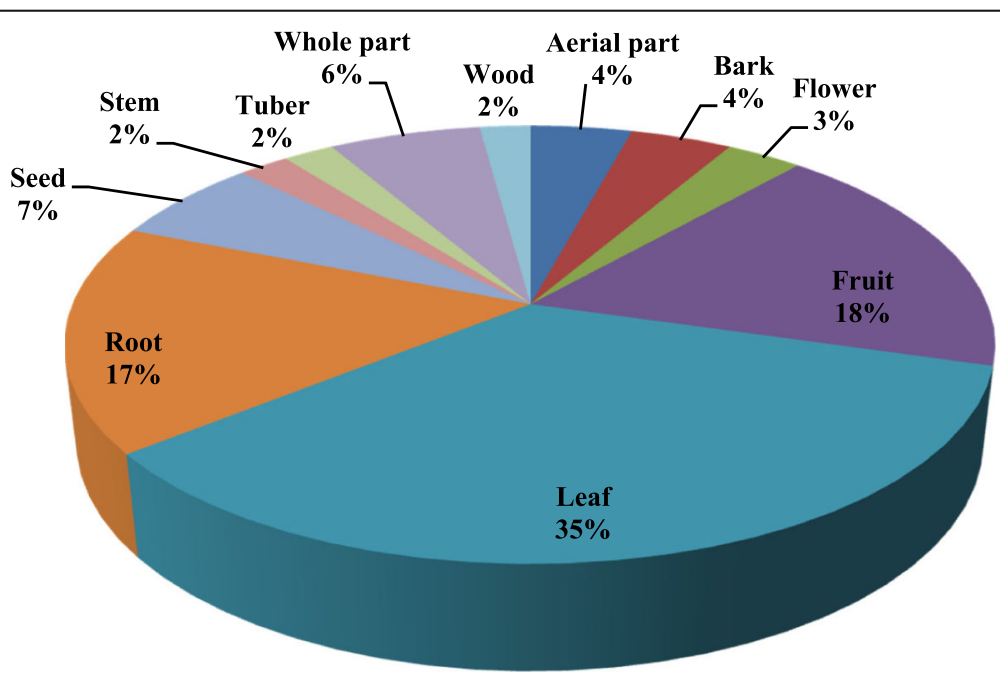

Fig. 4 Representation of plant parts used for various categories 
The most frequently used plant parts are leaves, fruits, roots, seeds, and whole part (Fig. 4). This result is similar to other investigations [41-48]. Easy availability of leaves with its higher metabolite content can be the reason for its preference $[49,50]$.

\section{The use value of plants}

Maximum plant species (32) were reported for ethnomedicinal uses followed by food (22 species), household uses (16 species), fruits (15 species), and fodder (14 species). Use value is an important tool for selecting the most valued plants of any region for its detailed pharmacological investigation [51]. Highest use value was reported for the plant species which had multiple uses in the area. On the basis of use value (UV), the most important plants in the study area were Pteridium aquilinum (1.72), Juglans regia (1.60), Corylus jacquemontii (1.44), Urtica dioica (1.4), Diplazium maximum (1.21), Angelica glauca (1.16), Rumex hastatus (1.09), and Rheum australe (1.04) (Table 1). More than one plant part is used for about $13 \%$ of the species. For example, the bark of Juglans regia is used in cleaning teeth, its fruit is edible, and the wood is used in various household purposes. Similarly, the fruits of Phytolacca acinosa are fed to poultry while its aerial parts are eaten as a vegetable. The fruits of Solanum nigrum are edible while the tender leaves are eaten to cure dysentery. The leaves of Betula utilis are used to cure the urinary infection, and the bark is used in thatching roofs as a waterproof medium.

\section{Informant consensus factor}

The highest informant consensus values were obtained for food and fruit plants $\left(F_{\mathrm{ic}}=0.99\right)$, followed by fodder plants and household uses $\left(F_{\text {ic }}=0.98\right)$ while it was least for the plants used for ethnomedicine $\left(F_{\text {ic }}\right.$ $=0.97$ ) (Table 2). Ethnobotanical uses of wild plants reported during the present investigation were found in agreement to previous studies [52, 53]. This reveals that wild plants play an important role in the sustenance of the people of the region. The various forest products not only fulfil their essential household requirements but wild vegetables and fruits provide essential vitamins and minerals for a healthy life [54]. A

Table 2 Use category and their factor informant consensus $\left(F_{\text {ic }}\right)$

\begin{tabular}{llll}
\hline Use category & Number of plant species & Use citations & $F_{\text {ic }}$ \\
\hline Food plants & 22 & 2127 & 0.99 \\
Fruit plants & 15 & 1410 & 0.99 \\
Fodder plants & 14 & 1179 & 0.98 \\
Household & 16 & 1358 & 0.98 \\
Ethnomedicinal plants & 32 & 1349 & 0.97 \\
\hline
\end{tabular}

Table 3 Fidelity level (Fl\%) of some important plant species for various use categories

\begin{tabular}{|c|c|c|}
\hline Use category & Important plants & $\mathrm{FI}(\%)$ \\
\hline \multirow[t]{6}{*}{ Food plants } & Diplazium maximum & 73.78 \\
\hline & Morchella esculenta & 77.78 \\
\hline & Polygonum aviculare & 83.2 \\
\hline & Phytolacca acinosa & 100 \\
\hline & Stellaria media & 100 \\
\hline & Urtica dioica & 100 \\
\hline \multirow[t]{7}{*}{ Fruit plants } & Berberis lycium & 100 \\
\hline & Corylus jacquemontii & 46.91 \\
\hline & Juglans regia & 51.39 \\
\hline & Prunus armeniaca & 100 \\
\hline & Prunus cornuta & 74.62 \\
\hline & Rubus ellipticus & 100 \\
\hline & Solanum nigrum & 52.88 \\
\hline \multirow[t]{7}{*}{ Fodder plants } & Acer caesium & 100 \\
\hline & Aesculus indica & 100 \\
\hline & Ailanthus altissima & 100 \\
\hline & Carpinus viminea & 92 \\
\hline & Corylus jacquemontii & 53.09 \\
\hline & Pteridium aquilinum & 49.57 \\
\hline & Quercus semecarpifolia & 100 \\
\hline \multirow[t]{13}{*}{ Ethnomedicinal plants } & Aconitum heterophyllum & 100 \\
\hline & Angelica glauca & 100 \\
\hline & Ajuga integrifolia & 100 \\
\hline & Betula utilis & 10.91 \\
\hline & Diplazium maximum & 26.22 \\
\hline & Morchella esculenta & 22.22 \\
\hline & Oxyria digyna & 19.44 \\
\hline & Pleurospermum brunonis & 17.59 \\
\hline & Polygonum aviculare & 16.80 \\
\hline & Prunus cornuta & 25.38 \\
\hline & Rheum australe & 36.88 \\
\hline & Rumex hastatus & 21.09 \\
\hline & Solanum nigrum & 47.12 \\
\hline \multirow{9}{*}{$\begin{array}{l}\text { Household (taboos, incense, } \\
\text { basketry, brooms, etc.) }\end{array}$} & Angelica glauca & 100 \\
\hline & Betula utilis & 89.09 \\
\hline & Boenninghausenia albiflora & 100 \\
\hline & Carpinus viminea & 8.00 \\
\hline & Juglans regia & 48.61 \\
\hline & Pleurospermum brunonis & 82.41 \\
\hline & Pteridium aquilinum & 50.43 \\
\hline & Rheum australe & 63.12 \\
\hline & Rumex hastatus & 78.91 \\
\hline
\end{tabular}


higher number of plants used for ethnomedicine by the tribal people indicate their dependency on locally available plant resources for curing various human and cattle related ailments. The complex ailments are healed by the local healers. This also signifies the unavailability of appropriate health care facilities in these remote regions. Aconitum heterophyllum, Bergenia stracheyi, and Verbascum thapsus with similar ethnomedicinal uses have been mentioned in the previous studies [55]. Roots were mostly used for curing various ailments because of easy availability in the dried form throughout the year [56].

\section{Fidelity level}

The fidelity level varied from 8 to $100 \%$ in all the use categories (Table 3). Phytolacca acinosa (100\%), Stellaria media (100\%), and Urtica dioica (100\%) were some of the species with high fidelity level used as food plants. The important species of wild fruits in the study area include Berberis lycium (100\%), Prunus armeniaca (100\%), and Rubus ellipticus (100\%). Some of the important fodder plants with high fidelity values (100\%) were Acer caesium, Aesculus indica, Ailanthus altissima, and Quercus semecarpifolia. Only a few plants with $100 \%$ fidelity were observed for ethnomedicine which were Aconitum heterophyllum, Angelica glauca, and Ajuga integrifolia while maximum plants in this category showed lower percentages of fidelity values varying from 10.91 to $47.12 \%$. For the household use, least fidelity percentage was observed for Carpinus viminea (8\%) while Angelica glauca and Boenninghausenia albiflora showed $100 \%$ fidelity values (Table 3). The fidelity level (Fl) helps in identifying the most preferred species for a particular use category. The high value of fidelity level $(100 \%)$ indicates the same method of use for a specific plant [57]. Seventy-one plant species had 100\% fidelity level. The ethnomedicinal plant use category had the maximum of 22 species with $100 \%$ fidelity level followed by food plant category with 18 species with $100 \%$ fidelity level.

\section{Plants used for commercial purposes}

With the onset of summer, the Gujjars start migrating to the higher altitudes with their cattle and stay in the temporary settlements called 'Adhwari's'. During this period, they uproot commercially important medicinal plants from the wild which they sell to local traders for financial gains [58]. The common medicinal plants harvested by them include Aconitum heterophyllum, Dactylorhiza hatagirea, Morchella esculenta, and Picrorhiza kurrooa (Table 4). Such indiscriminate exploitation of plant materials from nature can stress the natural population of these medicinal plants $[59,60]$. Many of the plant species are categorised as threatened in the state that includes Aconitum heterophyllum, Angelica glauca, Berberis aristata, Betula utilis, Dactylorhiza hatagirea, Jurinea macrocephala, Sinopodophyllum hexandrum, and Taxus wallichiana (Table 5). Though these plant resources play an important role in the subsistence of the people, it may not be sustainable in the near future [61].

\section{Comparison with the previous ethnobotanical studies}

The extensive literature review revealed the lesser known or new uses for 21 plant species from the study area (Table 5). Out of these, 13 plant species had ethnomedicinal uses, six household uses, and three edible uses. In the present study, leaf juice of Pleurospermum brunonis was used to cure skin infections while it was reported to cure jaundice and fever and used as an insect repellent in the previous studies [62,63]. The root of Asparagus adscendens was used to control hair fall while previously it has been reported as carminative and demulcent [64]. The decoction of leaves of Betula utilis was used to treat a urinary infection while the dried root powder of Trillium govanianum was used to cure arthritis. Morchella esculenta besides eaten as a vegetable was also used to cure a cold and cough while in the previous reports it is known to protect the stomach, nourish the lungs, and strengthen immunity [65-67]. The root of Oxalis corniculata was used to treat dyspepsia,

Table 4 Plants used for commercial purposes and their local market value in Tissa

\begin{tabular}{|c|c|c|c|c|c|}
\hline Scientific name & Common name & Family & Part used & Value & \\
\hline Aconitum heterophyllum & Patish & Ranunculaceae & Roots & 3500 & $/ \mathrm{kg}$ \\
\hline Dactylorhiza hatagirea & Salampanja & Orchidaceae & Roots & 2000 & $/ \mathrm{kg}$ \\
\hline Jurinea macrocephala & Dhoop & Leguminosae & Roots & 117 & $/ \mathrm{kg}$ \\
\hline Morchella esculenta & Gucchi & Morchellaceae & Whole plant & 7500 & $/ \mathrm{kg}$ \\
\hline Picrorhiza kurroa & Karu & Plantaginaceae & Rhizome & 500 & $/ \mathrm{kg}$ \\
\hline Selinum vaginatum & Bhootkeshi & Apiaceae & Roots & 200 & $/ \mathrm{kg}$ \\
\hline Valeriana jatamansi & Mushakbala & Caprifoliaceae & Roots & 220 & $/ \mathrm{kg}$ \\
\hline
\end{tabular}


Table 5 Comparison with the previous ethnobotanical studies

\begin{tabular}{|c|c|c|}
\hline Scientific name & $\begin{array}{l}\text { Uses in the } \\
\text { present study }\end{array}$ & Earlier use reports \\
\hline $\begin{array}{l}\text { Acer caesium Wall. ex Brandis } \\
\text { Sapindaceae }\end{array}$ & Fodder & The wood is used for making agricultural implements, fuelwood, soil binder, fodder $[72,73]$ \\
\hline $\begin{array}{l}\text { Aconitum heterophyllum Wall. } \\
\text { ex, Royle \# Ranunculaceae }\end{array}$ & Medicinal & It is used to treat a cough, cold, fever, and abdominal pain $[22,53,55]$ \\
\hline $\begin{array}{l}\text { Aesculus indica (Wall. ex } \\
\text { Cambess.) Hook. Sapindaceae }\end{array}$ & Fodder & Fodder, treatment of joint pains, fruits are edible $[59,74,53,66]$ \\
\hline $\begin{array}{l}\text { Ailanthus altissima (Mill.) } \\
\text { Swingle Simaroubaceae }\end{array}$ & Fodder & Fodder, reduce body swelling, bark juice mixed with milk to cure dysentery and diarrhoea [75-77] \\
\hline $\begin{array}{l}\text { Ajuga integrifolia Buch.-Ham. } \\
\text { Lamiaceae }\end{array}$ & Medicinal & Roots are used to treat snakebite, malaria, jaundice, mouth ulcers $[22,78]$ \\
\hline $\begin{array}{l}\text { Alnus nitida (Spach) Endl. } \\
\text { Betulaceae }\end{array}$ & Fodder & Medicinal, construction, furniture, fencing, roofing, fuel wood, fodder, utensils [78] \\
\hline $\begin{array}{l}\text { Amaranthus paniculatus L. } \\
\text { Amaranthaceae }\end{array}$ & Edible & Eaten as a vegetable, the seed is edible $[79,55]$ \\
\hline $\begin{array}{l}\text { Angelica glauca Edgew. \# } \\
\text { Apiaceae }\end{array}$ & $\begin{array}{l}\text { Medicinal, } \\
\text { household }\end{array}$ & Snake repellent, root powder used to cure flatulence, dyspepsia, oedema, arthritis $[80,60,23]$ \\
\hline $\begin{array}{l}\text { Arisaema tortuosum (Wall.) } \\
\text { Schott } \\
\text { Araceae }\end{array}$ & Edible & Tubers are boiled and eaten, aerial parts are eaten as vegetable $[80,60,23]$ \\
\hline $\begin{array}{l}\text { * Asparagus adscendens Roxb. } \\
\text { Asparagaceae }\end{array}$ & Medicinal & Carminative and demulcent [64] \\
\hline $\begin{array}{l}\text { Bauhinia variegata } \mathrm{L} . \\
\text { Fabaceae }\end{array}$ & Edible & Young shoots, leaves, and flowers are eaten as vegetable, used to make pickle $[36,55]$ \\
\hline $\begin{array}{l}\text { Berberis aristata DC. \# } \\
\text { Berberidaceae }\end{array}$ & Medicinal & Piles, eye infections, fruits edible $[81,23,82,55,66]$ \\
\hline $\begin{array}{l}\text { Berberis lycium Royle } \\
\text { Berberidaceae }\end{array}$ & Edible & $\begin{array}{l}\text { Whole plant part used to cure eye infections and diabetes, gum problems, kidney problems, fruits } \\
\text { edible }[23,53,66,83]\end{array}$ \\
\hline $\begin{array}{l}\text { Bergenia stracheyi (Hook.f. \& } \\
\text { Thomson) Engl. Saxifragaceae }\end{array}$ & Medicinal & $\begin{array}{l}\text { A decoction of the rhizome is taken twice a day while a paste is applied topically on eyelids, used } \\
\text { as fuel wood, diuretic }[63,69]\end{array}$ \\
\hline $\begin{array}{l}\text { *Betula utilis D.Don \# } \\
\text { Betulaceae }\end{array}$ & $\begin{array}{l}\text { Medicinal, } \\
\text { household }\end{array}$ & $\begin{array}{l}\text { Bark, leaf, and resin are used in rheumatism, bone fracture, joint pain, swellings, asthma, blood } \\
\text { purification, anti-cancerous, roof top and umbrella cover, fodder [84-86] }\end{array}$ \\
\hline $\begin{array}{l}\text { Boenninghausenia albiflora } \\
\text { (Hook.) Rchb. ex Meisn., } \\
\text { Rutaceae }\end{array}$ & Household & Antimicrobial, repel lice, fleas, and other insects $[62,87]$ \\
\hline $\begin{array}{l}\text { * Brucea javanica (L.) Merr } \\
\text { Simaroubaceae }\end{array}$ & Edible & Fodder, seed decoction taken orally for diarrhoea, malaria, and chronic diarrhoea $[88,89]$ \\
\hline $\begin{array}{l}\text { * Caltha palustris L. } \\
\text { Ranunculaceae }\end{array}$ & Medicinal & Diuretic, urinary infections, inflammation, used to clean the hands, gonorrhoea, kill maggots $[68,69]$ \\
\hline $\begin{array}{l}\text { Cannabis sativa L. } \\
\text { Cannabaceae }\end{array}$ & Edible & Joint pains, analgesic, sedative, antispasmodic, roasted seeds are eaten $[23,64,83,55]$ \\
\hline $\begin{array}{l}\text { * Carpinus viminea Wall. ex } \\
\text { Lindl. } \\
\text { Betulaceae }\end{array}$ & $\begin{array}{l}\text { Fodder, } \\
\text { household }\end{array}$ & $\begin{array}{l}\text { Fodder, the wood is used for making agricultural implements, sports equipment, and construction } \\
\text { of houses, used to heal bone fracture [90-92] }\end{array}$ \\
\hline $\begin{array}{l}\text { Cedrus deodara (Roxb. ex } \\
\text { D.Don) G.Don Pinaceae }\end{array}$ & Medicinal & Bitter, stomachic, anthelmintic, febrifuge, wounds, and cuts $[78,93]$ \\
\hline $\begin{array}{l}\text { Chenopodium album } \mathrm{L} \text {. } \\
\text { Amaranthaceae }\end{array}$ & Edible & Used as vegetable, fodder, laxative, jaundice, and urinary diseases $[94,43,82,64,81,83]$ \\
\hline $\begin{array}{l}\text { * Clinopodium vulgare L. } \\
\text { Lamiaceae }\end{array}$ & Edible & Antibacterial, antitumour, leaves are edible [95] \\
\hline $\begin{array}{l}\text { Commelina benghalensis } \mathrm{L} \text {. } \\
\text { Commelinaceae }\end{array}$ & Edible & Used to cure epilepsy, vaginal infection, eaten as vegetable $[43,55,96]$ \\
\hline Corydalis govaniana Wall. & Medicinal & Muscular pain, headache, leprosy, and rheumatism $[97,69,68]$ \\
\hline
\end{tabular}


Table 5 Comparison with the previous ethnobotanical studies (Continued)

\begin{tabular}{|c|c|c|}
\hline Scientific name & $\begin{array}{l}\text { Uses in the } \\
\text { present study }\end{array}$ & Earlier use reports \\
\hline $\begin{array}{l}\text { Corylus jacquemontii Decne. } \\
\text { Betulaceae }\end{array}$ & Edible, fodder & Medicinal, nuts edible, leaves used as fodder $[98,99]$ \\
\hline $\begin{array}{l}\text { Cotoneaster spp. } \\
\text { Rosaceae }\end{array}$ & Fodder & Fodder, walking sticks, baskets, fuel $[100,101]$ \\
\hline $\begin{array}{l}\text { Dactylorhiza hatagirea (D.Don) } \\
\text { Soó \# Orchidaceae }\end{array}$ & Medicinal & Given to person suffering from weakness [22] \\
\hline $\begin{array}{l}\text { *Daphne papyracea Wall. ex G. } \\
\text { Don Thymelaeaceae }\end{array}$ & Medicinal & $\begin{array}{l}\text { To cure bone disorders, intestinal complaints, ripen fruits edible, bark used for making paper [72, 101, 54, } \\
\text { 102] }\end{array}$ \\
\hline $\begin{array}{l}\text { Desmodium elegans DC. } \\
\text { Fabaceae }\end{array}$ & Fodder & $\begin{array}{l}\text { Fodder, leaf paste applied on cuts and wounds to avoid infection to stimulate healing, the bark is } \\
\text { used to clean teeth }[103,38]\end{array}$ \\
\hline $\begin{array}{l}\text { Diplazium maximum (D. Don) } \\
\text { C. Chr. Athyriaceae }\end{array}$ & $\begin{array}{l}\text { Medicinal, } \\
\text { edible }\end{array}$ & Muscular pain, young shoots are eaten as a vegetable $[23,36,66,102]$ \\
\hline $\begin{array}{l}\text { Dysphania botrys (L.) Mosyakin } \\
\& \text { Clemants Amaranthaceae }\end{array}$ & Edible & Popular flavouring for a soup of meat, cheese, and barley $[104,105]$ \\
\hline $\begin{array}{l}\text { Elaeagnus parvifolia Wall. ex } \\
\text { Royle Elaeagnaceae }\end{array}$ & Edible & Fruits edible, medicinal $[78,54]$ \\
\hline $\begin{array}{l}\text { * Epipactis helleborine (L.) } \\
\text { Crantz } \\
\text { Orchidaceae }\end{array}$ & Household & Used to treat insanity, gouts, headache, and stomach ache [106] \\
\hline $\begin{array}{l}\text { Fagopyrum esculentum } \\
\text { Moench } \\
\text { Polygonaceae }\end{array}$ & Edible & Stomach ulcer, tumour, jaundice, vegetable $[63,66]$ \\
\hline $\begin{array}{l}\text { Ficus spp. } \\
\text { Moraceae }\end{array}$ & Fodder & Fodder, purgative, antiseptic $[107,78]$ \\
\hline $\begin{array}{l}\text { Fragaria indica Andrews } \\
\text { Rosaceae }\end{array}$ & Edible & Fruits are edible [99] \\
\hline $\begin{array}{l}\text { Fragaria nubicola (Lindl. ex } \\
\text { Hook.f.) Lacaita Rosaceae }\end{array}$ & Edible & Fruits are edible $[82,55]$ \\
\hline $\begin{array}{l}\text { Fragaria vesca L. } \\
\text { Rosaceae }\end{array}$ & Edible & Fruits are edible [52] \\
\hline $\begin{array}{l}\text { Gagea lutea (L.) Ker Gawl. } \\
\text { Liliaceae }\end{array}$ & Edible & Dried tubers used as spice [108] \\
\hline $\begin{array}{l}\text { Impatiens spp. } \\
\text { Balsaminaceae }\end{array}$ & Fodder & Fodder, the colour obtained is used as nail paint $[100,78]$ \\
\hline $\begin{array}{l}\text { Jasminum humile L. } \\
\text { Oleaceae }\end{array}$ & Medicinal & Powdered roots used as anthelmintic, diuretic, skin diseases, headache, mouth rash, ringworm $[109,77,110]$ \\
\hline $\begin{array}{l}\text { Juglans regia } \mathrm{L} \text {. } \\
\text { Juglandaceae }\end{array}$ & $\begin{array}{l}\text { Edible, } \\
\text { household }\end{array}$ & Fruit edible, fuel, timber, fruit tonic taken for back pain $[103,94,89,53]$ \\
\hline $\begin{array}{l}\text { Jurinea macrocephala DC. \# } \\
\text { Asteraceae }\end{array}$ & Household & $\begin{array}{l}\text { Roots are used during religious ceremonies for incense, root decoction is given once per day to } \\
\text { treat cold and cough [111] }\end{array}$ \\
\hline $\begin{array}{l}\text { Malva neglecta Wallr. } \\
\text { Malvaceae }\end{array}$ & Edible & A cough, cold, malaria, kidney disorders and cooked as a vegetable $[23,69,112]$ \\
\hline $\begin{array}{l}\text { * Morchella esculenta (L.: Fr.) } \\
\text { Pers. Morchellaceae }\end{array}$ & $\begin{array}{l}\text { Edible, } \\
\text { medicinal }\end{array}$ & Cooked and eaten, protect the stomach, nourish the lungs, and strengthen immunity $[65,66,67]$ \\
\hline $\begin{array}{l}\text { Neolitsea pallens (D. Don) } \\
\text { Momiy. \& H. Hara } \\
\text { Lauraceae }\end{array}$ & Fodder & Fodder, juice of fruits is used to treat scabies and eczema, seeds oil is used as an antidote $[103,44,113]$ \\
\hline $\begin{array}{l}\text { * Onosma hispida Wall. ex G. } \\
\text { Don Boraginaceae }\end{array}$ & Medicinal & Fever, pain relief, wounds, infectious diseases, hair colour $[114,115]$ \\
\hline $\begin{array}{l}\text { * Oxalis corniculata L. } \\
\text { Oxalidaceae }\end{array}$ & Medicinal & $\begin{array}{l}\text { Blood purifier, appetiser, cure piles, diarrhoea, toothache, cough cure scorpion stings and skin diseases, } \\
\text { aerial part is eaten as a vegetable }[116-118,55,119,43,64,120]\end{array}$ \\
\hline $\begin{array}{l}\text { Oxyria digyna (L.) Hill } \\
\text { Polygonaceae }\end{array}$ & $\begin{array}{l}\text { Edible, } \\
\text { medicinal }\end{array}$ & Used to make chutney, digestive and purgative [66] \\
\hline
\end{tabular}


Table 5 Comparison with the previous ethnobotanical studies (Continued)

\begin{tabular}{|c|c|c|}
\hline Scientific name & $\begin{array}{l}\text { Uses in the } \\
\text { present study }\end{array}$ & Earlier use reports \\
\hline $\begin{array}{l}\text { * Persicaria amplexicaulis } \\
\text { (D.Don) Ronse Decr., } \\
\text { Polygonaceae }\end{array}$ & Edible & $\begin{array}{l}\text { Used to treat skin diseases, jaundice, dysentery, leucorrhoea, fever, headache, indigestion, stomach } \\
\text { pain, and blood purifier, effective in flu, fever, and joints }[121-124,53]\end{array}$ \\
\hline $\begin{array}{l}\text { Persicaria hydropiper (L.) } \\
\text { Delarbre Polygonaceae }\end{array}$ & Edible & Eaten as vegetable, dye plant $[119,52]$ \\
\hline $\begin{array}{l}\text { Phytolacca acinosa Roxb. } \\
\text { Phytolaccaceae }\end{array}$ & Edible & $\begin{array}{l}\text { Used to treat acne, eaten as a vegetable, root decoction is taken for cervical erosion, digestibility } \\
\text { ulcer, liver ascites, constipation, diuresis }[23,94,89]\end{array}$ \\
\hline $\begin{array}{l}\text { Picrorhiza kurrooa Royle \# } \\
\text { Plantaginaceae }\end{array}$ & Medicinal & Fever, jaundice, improve appetite and skin infection $[125,22,23]$ \\
\hline $\begin{array}{l}\text { * Pleurospermum brunonis } \\
\text { Benth. ex C.B. Clarke } \\
\text { Apiaceae }\end{array}$ & $\begin{array}{l}\text { Medicinal, } \\
\text { household }\end{array}$ & Whole plant used to cure jaundice, fever, insect repellent, incense $[62,63]$ \\
\hline $\begin{array}{l}\text { * Polygonum aviculare L. } \\
\text { Polygonaceae }\end{array}$ & $\begin{array}{l}\text { Edible, } \\
\text { medicinal }\end{array}$ & Eaten as a vegetable, treat dysentery and diarrhoea $[119,43]$ \\
\hline $\begin{array}{l}\text { * Primula floribunda Wall. } \\
\text { Primulaceae }\end{array}$ & Household & $\begin{array}{l}\text { Used to treat headache, rheumatism, flowers are believed to have supernatural power to ward off } \\
\text { devils and people knowing witchcraft, flowers increase the beauty of hair of ladies }[70,71]\end{array}$ \\
\hline $\begin{array}{l}\text { Prunus armeniaca L. } \\
\text { Rosaceae }\end{array}$ & Edible & Heal constipation in cattle, fruits are edible $[53,66]$ \\
\hline $\begin{array}{l}\text { * Prunus cornuta (Wall. ex } \\
\text { Royle) Steud. } \\
\text { Rosaceae }\end{array}$ & $\begin{array}{l}\text { Edible, } \\
\text { medicinal }\end{array}$ & Used to cure anaemia, fruits are edible $[23,66]$ \\
\hline $\begin{array}{l}\text { Prunus persica (L.) Batsch } \\
\text { Rosaceae }\end{array}$ & Edible & Fruits are edible [66] \\
\hline $\begin{array}{l}\text { Pteridium aquilinum (L.) Kuhn } \\
\text { Dennstaedtiaceae }\end{array}$ & $\begin{array}{l}\text { Fodder, } \\
\text { household }\end{array}$ & $\begin{array}{l}\text { Tender fronds used as vegetables, green fronds as fodder, good soil binder, used to cure diabetes, } \\
\text { abdominal oedema }[126,23]\end{array}$ \\
\hline $\begin{array}{l}\text { Quercus semecarpifolia Sm. } \\
\text { Fagaceae }\end{array}$ & Fodder & Fodder, timber, construction, furniture, fencing, roofing, fuel wood, medicinal $[78,127]$ \\
\hline $\begin{array}{l}\text { Ranunculus spp. } \\
\text { Ranunculaceae }\end{array}$ & Fodder & Fodder plant, counter irritant swelling in testes, fever, stomach worms $[78,127]$ \\
\hline $\begin{array}{l}\text { Rheum australe D. Don } \\
\text { Polygonaceae }\end{array}$ & $\begin{array}{l}\text { Household, } \\
\text { medicinal }\end{array}$ & Cleaning tooth, given to animals lost their appetite, asthma, fever, pneumonia, vegetable $[22,63]$ \\
\hline $\begin{array}{l}\text { Rhododendron arboreum Sm. } \\
\text { Ericaceae }\end{array}$ & Edible & Used as local brew, used to make chutney $[128,66]$ \\
\hline $\begin{array}{l}\text { * Rhododendron } \\
\text { campanulatum D.Don, } \\
\text { Ericaceae }\end{array}$ & Medicinal & Leaves are mixed with tobacco and used as snuff to cure a cold [68] \\
\hline $\begin{array}{l}\text { Rosa macrophylla Lindl. } \\
\text { Rosaceae }\end{array}$ & Medicinal & Used in cold and cough, flowers are edible, fruits are edible, stomach ache $[23,82]$ \\
\hline $\begin{array}{l}\text { Rubus ellipticus Sm. } \\
\text { Rosaceae }\end{array}$ & Edible & Fruits are eaten to cure indigestion [23] \\
\hline $\begin{array}{l}\text { Rubus niveus Thunb. } \\
\text { Rosaceae }\end{array}$ & Edible & Fruits are edible $[94,36]$ \\
\hline $\begin{array}{l}\text { * Rumex hastatus D. Don } \\
\text { Polygonaceae }\end{array}$ & $\begin{array}{l}\text { Medicinal, } \\
\text { household }\end{array}$ & Used to cure foot disease in cattle, used to cure jaundice, leaves eaten as a vegetable $[23,43,82]$ \\
\hline $\begin{array}{l}\text { * Sarcococca saligna (D. Don) } \\
\text { Müll. Arg. } \\
\text { Buxaceae }\end{array}$ & Household & Timber, fodder, fuel, and leaves in the ceiling of a roof of houses as a waterproof medium $[129,130]$ \\
\hline $\begin{array}{l}\text { Selinum vaginatum C.B. Clarke } \\
\text { Apiaceae }\end{array}$ & Household & Used in making brew and incense making $[62,66]$ \\
\hline $\begin{array}{l}\text { Sinopodophyllum hexandrum } \\
\text { (Royle) T.S.Ying \# } \\
\text { Berberidaceae }\end{array}$ & Medicinal & Cancer curing, bloating and appetite loss in cattle, fruit is edible $[23,53,94,52]$ \\
\hline $\begin{array}{l}\text { * Solanum nigrum L. } \\
\text { Solanaceae }\end{array}$ & $\begin{array}{l}\text { Edible, } \\
\text { medicinal }\end{array}$ & Vegetable, headache, fruits edible $[119,55,53]$ \\
\hline
\end{tabular}


Table 5 Comparison with the previous ethnobotanical studies (Continued)

\begin{tabular}{|c|c|c|}
\hline Scientific name & $\begin{array}{l}\text { Uses in the } \\
\text { present study }\end{array}$ & Earlier use reports \\
\hline $\begin{array}{l}\text { Sorbaria tomentosa (Lindl.) } \\
\text { Rehder } \\
\text { Rosaceae }\end{array}$ & Medicinal & $\begin{array}{l}\text { The flowers are grinded in milk and the resulted paste is applied to burns and wounds, fruits } \\
\text { smoked in the treatment of asthma }[38,39,131]\end{array}$ \\
\hline $\begin{array}{l}\text { Spiraea canescens D.Don. } \\
\text { Rosaceae }\end{array}$ & Household & Basket making $[69,103]$ \\
\hline $\begin{array}{l}\text { Stellaria media (L.) Vill. } \\
\text { Caryophyllaceae }\end{array}$ & Edible & $\begin{array}{l}\text { Leaf paste applied to cure joint pains and swellings, seed powder is given to children with milk to } \\
\text { cure skin infection and allergy and leaf paste is applied to heal wounds caused by burning or frost, } \\
\text { eaten as a vegetable }[132,43,133]\end{array}$ \\
\hline $\begin{array}{l}\text { Taxus wallichiana Zucc. \# } \\
\text { Taxaceae }\end{array}$ & Edible & Refreshing tea, cancer curing, and thatching roofs $[22,23]$ \\
\hline $\begin{array}{l}\text { * Trillium govanianum Wall. ex } \\
\text { D.Don } \\
\text { Melanthiaceae }\end{array}$ & Medicinal & Used to cure dysentery, reproductive disorder $[125,103,23]$ \\
\hline $\begin{array}{l}\text { Urtica dioca } \mathrm{L} \text {. } \\
\text { Urticaceae }\end{array}$ & $\begin{array}{l}\text { Edible, } \\
\text { medicinal }\end{array}$ & Used to treat skin diseases, soup making, eaten as a vegetable $[23,82,36]$ \\
\hline $\begin{array}{l}\text { Valeriana jatamansi Jones } \\
\text { Caprifoliaceae }\end{array}$ & Household & $\begin{array}{l}\text { Roots used to cure a stomachache, valerian root has been used for a century as a relaxing and } \\
\text { sleep promoting plant }[59,23] \text {. }\end{array}$ \\
\hline $\begin{array}{l}\text { Verbascum thapsus L. } \\
\text { Scrophulariaceae }\end{array}$ & Medicinal & Indigestion in cattle [55] \\
\hline $\begin{array}{l}\text { Viburnum mullaha Buch.-Ham. } \\
\text { ex D. Don Adoxaceae }\end{array}$ & Edible & Used to cure a cold and cough, fruits eaten $[23,53]$ \\
\hline
\end{tabular}

*Plants with new or lesser known ethnobotanical uses reported in the present study

\# Threatened wild plants of Himachal Pradesh, India [134]

and aerial part of Polygonum aviculare was used to cure pneumonia. Seed powder of Prunus cornuta was administrated orally to cure diabetes while the same species was reported against anaemia [23]. The tender leaves of Solanum nigrum were reported to treat dysentery while it is known to cure a headache [55]. The animal ailments like a cough and a cold of buffalos were cured using leaves of Rhododendron campanulatum and Daphne papyracea. The worm-infected sores and wounds of cattle were healed using leaves of Caltha palustris while it has been reported to cure various other ailments like urinary infections and inflammation in the previous studies $[68,69]$. A number of plants were used by people for household uses like leaves and roots of Primula floribunda for cleaning milk containers to remove the oiliness and odour of the utensils while it has been reported for its use to ward off devils and as a hair decorator by women [70, 71]. Very interesting information was provided by the Gujjars about the use of root of Persicaria amplexicaulis in tea making which they consume very often because of easy availability of the plant, good flavour, and a number of health benefits. Fruits of Brucea javanica were used in making chutney (sauce) while the cracked seeds of Clinopodium vulgare were used in various recipes. They make brooms from the stems of Sarcococca saligna and shoes from the bark of Carpinus viminea. The poor economic conditions of the Gujjars and remoteness of the area have made them adopt indigenous knowledge passed through their ancestry.

\section{Conclusions}

The Gujjars of Churah region constitute an important segment of the population in the region who have in-depth knowledge of diverse plant uses that can be linked back to their hereditary profession of pastoralism (Fig. 5). The infinite ethnobotanical knowledge of this tribe can also be related to their greater dependency on the wild plant resources for their sustenance because of poor living standards, illiteracy, and poverty. The younger generation is also actively involved in the seasonal activity of semi-nomadic pastoralism, and therefore, they had sound knowledge of the traditional knowledge though it was mostly concentrated in the older informants.

The present study revealed the in-depth ethnobotanical knowledge of the Gujjars. The local communities have accumulated this immense knowledge through experimentation and modifications since centuries. Knowledge and use of medicinal plants to cure various ailments is part of their life and culture that requires preservation of this indigenous knowledge. In the present scenario, it forms an essential component of sustainable development. But this traditional knowledge which is transferred from one generation to another 


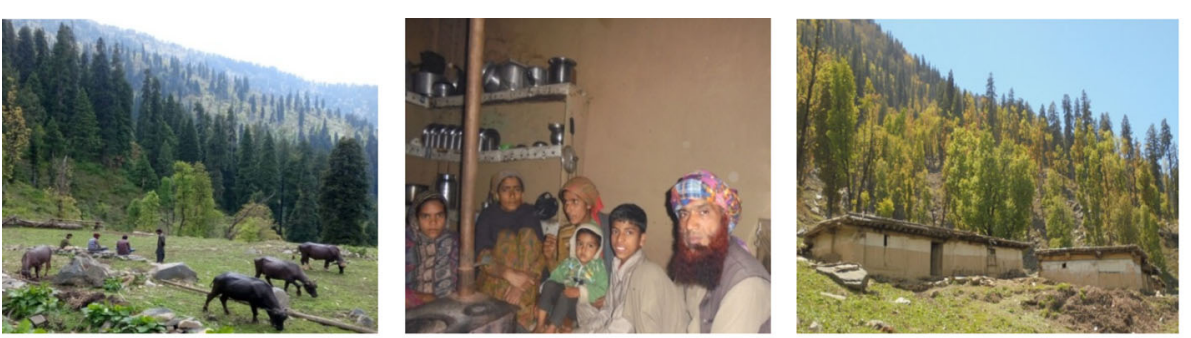

Different views at higher altitudes in the temporary settlement of Gujjars called the 'Adhwari's'

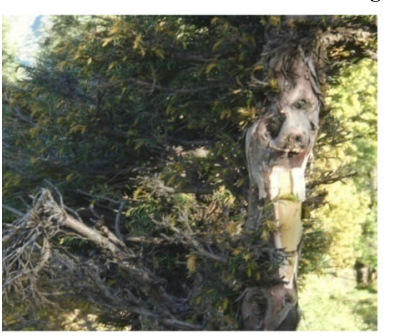

Taxus wallichiana

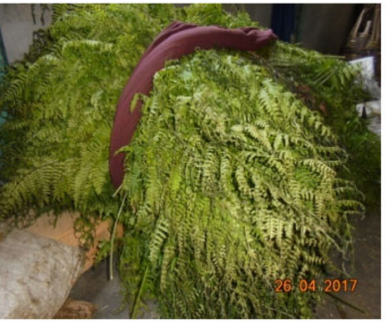

Pteridium aquilinum

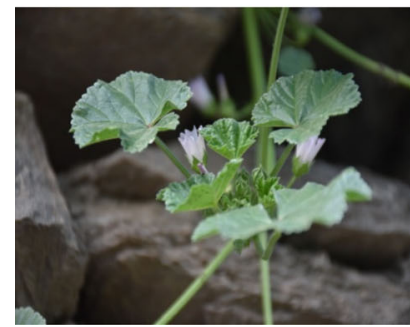

Malva neglecta

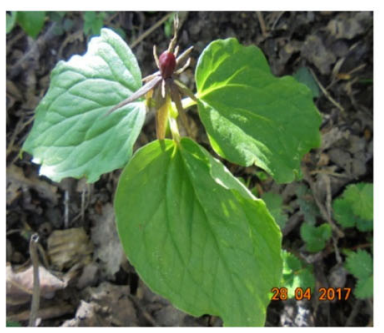

Trillium govanianum

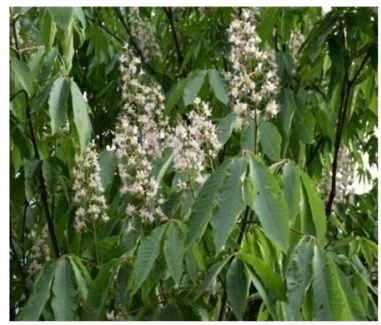

Aesculus indica

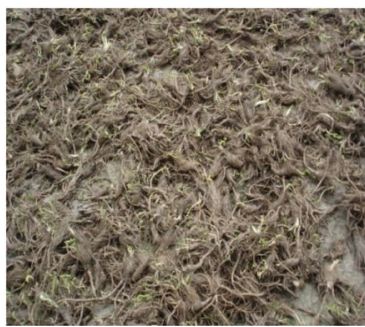

Selinum vaginatum

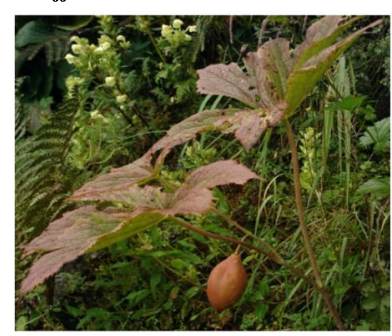

Sinopodophyllum hexandrum

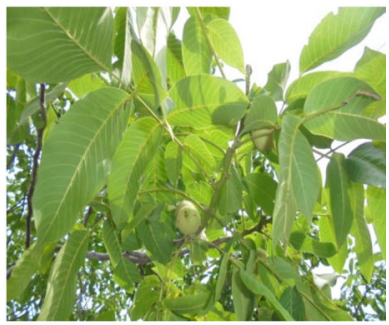

Juglans regia

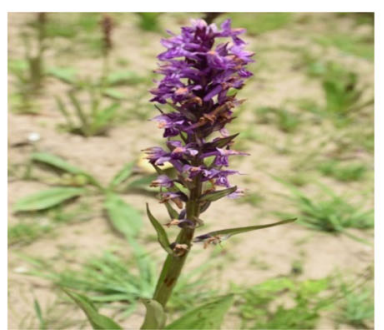

Dactylorhiza hatagirea

Fig. 5 Glimpses of photographs clicked during the entire period of study

through the words of mouth is eroding exigently. Thus, there is an urgent need for the documentation of this traditional knowledge and in-depth phytochemical investigations to evaluate potentially active compounds of the plant species to prove their efficacy.

It is essentially required to develop agro technological tools for plant species for which the same is lacking to ensure plantation in the forests/community lands available in the villages to check unsustainable harvesting of wild edibles. Value addition and product development of wild fruit plants can provide an alternate source of livelihood to the rural people. Thus, bioprospection and phytochemical profiling and evaluation of economically viable products can lead to the optimum harnessing of Himalayan bioresources in this region.

\section{Additional file}

Additional file 1: Questionnaire for documentation of ethno-botanical related TKS in the IHR from local resource persons and traditional healers (DOCX $19 \mathrm{~kb})$

\section{Acknowledgements}

The authors are thankful to the Director, CSIR-IHBT, Palampur for providing facilities and encouragement. We are grateful to DST, Govt. of India for the financial assistance provided under a sponsored project entitled "Network programme on the convergence of traditional knowledge system for sustainable development in the Indian Himalayan Region" and Prof. S.C. Garkoti, JNU for his constant support and cooperation. We are highly grateful to the Gujjars of the Churah region for sharing valuable information without any hurdle and support of officials of various line departments is also duly acknowledged. We are grateful to the Editor and the Reviewers for their valuable suggestions which helped us in improving this manuscript. 


\section{Funding}

Funds for the study were provided by DST, Govt. of India funded project GAP-0189.

\section{Availability of data and materials}

All data generated or analyzed during this study are included in this published article.

\section{Authors' contributions}

$D R$ and $A B$ carried out field surveys and data recording and prepared the manuscript. BL designed the study and edited the manuscript. Both authors read and approved the final manuscript.

\section{Ethics approval and consent to participate}

Prior consent of the informants was taken while conducting these studies. This was done to adhere to the ethical standards of human participation in scientific research.

\section{Consent for publication}

\section{Not applicable}

\section{Competing interests}

The authors declare that they have no competing interests.

\section{Publisher's Note}

Springer Nature remains neutral with regard to jurisdictional claims in published maps and institutional affiliations.

Received: 14 November 2018 Accepted: 16 January 2019

Published online: 11 February 2019

\section{References}

1. Nath V, Khatri PK. Traditional knowledge on ethnomedicinal uses prevailing in tribal pockets of Chhindwara and Betul districts, Madhya Pradesh, India. Afr J Pharm and Pharmacol. 2010;4(9):662-70.

2. Mishra S, Mishra MK. Ethno-botanical study of plants with edible underground parts of south Odisha, India. Int J Res Agri food sci. 2014;4(2):51-8.

3. Britta OM, Tuyet HT, Duyet HN, Dung NNX. Food, feed or medicine: the multiple functions of edible wild plants in Vietnam. Econ Bot. 2003;57:103-17.

4. Setalaphruk C, Price LL. Children's traditional ecological knowledge of wild food resources: a case study in a rural village in Northeast Thailand. J Ethnobiol Ethnomed. 2007:3:33.

5. Sundriyal M, Sundriyal RC. Wild edible plants of the Sikkim Himalaya: nutritive values of selected species. Econ Bot. 2001:55:377-90.

6. Verma AK. Forest as the material basis of tribal society during colonial period" in Chittarajan Kumar Paty (ed) Forest Government And Tribe (New Delhi: concept publishing company). 2007; 113-122.

7. Singh A. Cultural significance and diversity of ethnic foods of North East India. Indian J Tradit Knowl. 2006;6:79-94.

8. Rashid A, Anand VK, Serwar J. Less known wild edible plants used by the Gujjar tribe of district Rajouri. J\& K state Int J Bot. 2008;4(2):219-24.

9. Khoshoo TN. Conservation of biodiversity in biosphere. In: Khoshoo TN, Sharma M, editors. Indian geosphere biosphere programme some aspects. Allahabad, India: Nation Academy of Sciences; 1991. p. 178-233.

10. Sharma PK. Ethnobotanical studies of Gaddis- a tribal community in district Kangra, H.P. Ph.D Thesis submitted to Yaswant Singh Parmar University of Horticulture and Forestry; 1998.

11. Tambs-Lyche H. Power, profit and poetry: traditional society in Kathiawar. Western India: Manohar Publishers, New Delhi; 1997.

12. Sahni B. Socio-religious dichotomy among the Gujjars of Himachal Pradesh. Int J Management \& Soc Sci. 2016;4(2):2455-267.

13. Negi TS. The scheduled tribes of Himachal Pradesh: a profile. Meerut: Raj Publishers; 1982. p. 117.

14. Census of India. 2011; Data retrieved from http://www.censusindia.gov.in/ 2011census/population_enumeration.aspx

15. Crooke W. The tribes and castes of the North-Western India Vol.-II. Delhi: Cosmo Publication; 1974. p. 440.

16. Farooquee NA, Saxena KG. Conservation and utilization of medicinal plants in high hills of the central Himalayas. Environ Conserv. 1996;23(1):75-80.

17. Ssegawa P, Kasenene JM. Medicinal plant diversity and uses in the Sango bay area, southern Uganda. J Ethnopharmacol. 2007;113:521-40.
18. Bhatia H, Sharma YP, Manhas RK, Kumar K. Ethnomedicinal plants used by the villagers of district Udhampur, J\&K, India. J Ethnopharmacol. 2014;151(2): 1005-18.

19. FAO. The state of food insecurity in the world, Rome.2009.

20. Khoshbakht K, Hammer K. Savadkouh (Iran) - an evolutionary center for fruit trees and shrubs. Genet Resour Crop Evol. 2005;53:641-51.

21. Bunalema L, Obakiro S, Tabuti JRS, Waako P. Knowledge on plants used traditionally in the treatment of tuberculosis in Uganda. J Ethnopharmacol. 2014;151:999-1004.

22. Guleria V, Vasishth A. Ethnobotanical uses of wild medicinal plants by Guddi and Gujjar tribes of Himachal Pradesh. Ethnobotanical Leaflets. 2009;13:1158-67.

23. Rani S, Rana JC, Rana PK. Ethnomedicinal plants of Chamba district, Himachal Pradesh, India. J Med Res. 2013;7(42):3147-57.

24. Chowdhery HJ, Wadhwa BM. Flora of Himachal Pradesh: analysis 1984; Vol.-I.

25. Singh $H$, Sharma M. Flora of Chamba District, Himachal Pradesh, vol. 16. Dehra Dun: Bishen Singh Mahendra Pal Singh; 2006. p. 881

26. Polunin O, Stainton A. Flowers of the Himalaya. In: Seventh impression. New Delhi: Oxford University Press; 2005

27. Phillips O, Gentry AH, Reynel C, Wilki P, Gavez-Durand CB. Quantitative ethnobotany and Amazonian conservation. Conserv Biol. 1994:8:225-48.

28. Trotter $\mathrm{R}$, Logan M. Informant consensus, a new approach for identifying potentially effective medicinal plants, in Plants in Indigenous Medicine and Diet, Bio-behavioural Approaches (ed. N.L. Etkin), Redgrave Publishers, Bedford Hills, New York. 1986; 91-112.

29. Heinrich M, Ankli A, Frei B, Weimann C, Sticher O. Medicinal plants in Mexico: healers' consensus and cultural importance. Soc Sci Med. 1998;47:1863-75.

30. Gazzaneo LRS, Lucena RFP, Albuquerque UP. Knowledge and use of medicinal plants by local specialists in a region of Atlantic Forest in the state of Pernambuco (Northeastern Brazil). J Ethnobiol Ethnomed. 2005;1:9

31. Sharma R, Manhas RK, Magotra R. Ethnoveterinary remedies of diseases among milk yielding animals in Kathua, Jammu and Kashmir, India. J Ethnopharmacol. 2012;141(1):265-72.

32. Xavier TF, Kannan M, Lija L, Auxillia A, Rose AKF, Kumar SS. Ethnobotanical study of Kani tribes in Thoduhills of Kerala, South India. J Ethnopharmacol. 2014;152:78-90

33. Friedman J, Yaniv Z, Dafni A, Palewitch D. A preliminary classification of the healing potential of medicinal plants, based on a rational analysis of an ethnopharmacological field survey among Bedouins in the Negev desert, Israel. J Ethnopharmacol. 1986;16:275-87.

34. Musa MS, Abdelrasool FE, Elsheikh EA, Ahmed LAMN, Mahmoud ALE, Yagi SM. Ethnobotanical study of medicinal plants in the Blue Nile State, Southeastern Sudan. Journal of Medicinal Plants Research. 2011:5:4287-97.

35. Łuczaj Ł. Archival data on wild food plants used in Poland in 1948. J Ethnobiol Ethnomed. 2008:4:4.

36. Uprety Y, Poudel RC, Shrestha KK, Rajbhandary S, Tiwari NN, Shrestha UB, Asselin $\mathrm{H}$. Diversity of use and local knowledge of wild edible plant resources in Nepal. J Ethnobiol Ethnomed. 2012:8:16.

37. Sharma PK, Chauhan NS, Lal B. Observations on the traditional phytotherapy among the inhabitants of Parvati valley in western Himalaya, India. J Ethnopharmacol. 2004;92:167-76

38. Kumar S, Hamal IA. Wild edibles of Kishtwar high altitude national park in northwest Himalaya, Jammu, and Kashmir (India). Ethnobotanical Leaflets. 2009:13:195-202.

39. Dangwal LR, Rana CS, Sharma A. Ethno-medicinal plants from the transitional zone of Nanda Devi Biosphere Reserve, district Chamoli, Uttarakhand (India). Indian J Nat Prod Resour. 2011;2(1):116-20.

40. Singh B, Bedi YS. Eating from raw wild plants in Himalaya: traditional knowledge documentary on Sheena tribe in Kashmir. Indian J Nat Prod Resour. 2017:8(3):269-75.

41. Giday M, Asfaw Z, Woldu Z. Medicinal plants of the Meinit ethnic group of Ethiopia: an ethnobotanical study. J Ethnopharmacol. 2009;124:513-21.

42. Ugulu I, Baslar S, Yorek N, Dogan Y. The investigation and quantitative ethnobotanical evaluation of medicinal plants used around Izmir province. J Med Plant Res. 2009:3:345-67.

43. Abbasi AM, Khan MA, Shah MH, Shah MM, Pervez A, Ahmed M. Ethnobotanical appraisal and cultural values of medicinally important wild edible vegetables of Lesser Himalayas- Pakistan. J Ethnobiol Ethnomed. 2013:9:66.

44. Bhat JA, Kumar M, Bussmann RW. Ecological status and traditional knowledge of medicinal plants in Kedarnath Wildlife Sanctuary of Garhwal Himalaya, India. J Ethnobiol Ethnomed. 2013;9:1. 
45. Ullah M, Khan MU, Mahmood A, Malik R, Hussain M, Wazir SM, Daud M, Khan ZK. An ethnobotanical survey of indigenous medicinal plants in Wana district south Waziristan agency, Pakistan. J Ethnopharmacol. 2013;150:918-24.

46. Sadeghi Z, Mahmood A. Ethno-gynaecological knowledge of medicinal plants used by Baluch tribes, southeast of Baluchistan, Iran, Brazilian. J Pharmacogn. 2014:24:706-15.

47. Araya S, Abera B, Giday M. Study of plants traditionally used in public and animal health management in Seharti Samre District, Southern Tigray, Ethiopia. J Ethnobiol Ethnomed. 2015;11:22.

48. Guler B, Manav E, Ugurlu E. Medicinal plants used by traditional healers in Bozuyuk (Bilecik-Turkey). J Ethnopharmacol. 2015;173:39-47.

49. Ghorbani A. Studies on pharmaceutical ethno botany in the region of Turkmen Sahra north of Iran (Part 1): general results. J Ethnopharmacol. 2005;102:58-68.

50. Weckerle CS, Huber FK, Yang YP, Sun WB. Plant knowledge of the Shuhi in the Hengduan Mountains, southwest China. Econ Bot. 2006;60:3-23.

51. Sadeghi Z, Kuhestani K, Abdollahi V, Mahmood A. Ethnopharmacological studies of indigenous medicinal plants of Saravan region, Baluchistan, Iran. J Ethnopharmacol. 2014;153:111-8.

52. Li F, Zhuo J, Bo L, Jarvis D, Long C. Ethnobotanical study on wild plants used by Lhoba people in Milin Country, Tibet. J Ethnobiol Ethnomed. 2015;11:23.

53. Aryal KP, Poudel S, Chaudhary RP, Chattri N, Chaudhary P, Ning W, Kotru R. Diversity and use of wild and non cultivated edible plants in the Western Himalaya. J Ethnobiol Ethnomed. 2018;14:10.

54. Tsering J, Gogoi BJ, Hui PK, Tam N, Tag H. Ethnobotanical appraisal on wild edible plants used by the Monpa community of Arunachal Pradesh. Indian J Tradit Knowl. 2017;16(4):626-37.

55. Thakur M, Asrani RK, Thakur S, Sharma PK, Patil RD, Lal B, Parkash O. Observations on traditional usage of ethnomedicinal plants in humans and animals of Kangra and Chamba districts of Himachal Pardesh in NorthWestern Himalaya, India. J Ethnopharmacol. 2016;191:280-300.

56. Singh A, Nautiyal MC, Kunwar RP, Bussmann RW. Ethnomedicinal plants used by local inhabitants of Jakholi block, Rudraprayag district, western Himalaya, India. J Ethnobiol Ethnomed. 2017;13:49.

57. Srithi K, Balslev H, Wangpakapattanawong P, Srisanga P, Trisonthi C. Medicinal plant knowledge and its erosion among the Mien (Yao) in northern Thailand. J Ethnopharmacol. 2009;123:335-42.

58. Balemie K, Kebebew F. Ethnobotanical study of wild edible plants in Derashe and Kucha Districts, South Ethiopia. J Ethnobiol Ethnomed. 2006;2:53.

59. McCabe S. Complementary herbal and alternative drugs in clinical practice. Perspect Psychiatr Care. 2002;38:98-107.

60. Thakur KS, Kumar M, Bawa R, Bussmann RW. Ethnobotanical study of herbaceous flora along an altitudinal gradient in Bharmour forest division. In: District Chamba of Himachal Pradesh. India: Evidence based Complement Altern Medicine; 2014.

61. Dorji Y. Women's roles in wild yam, conservation, management and use in Bhutan. In: Khadka M, Verma R, editors. Gender and biodiversity management in the Greater Himalayas, ICIMOD 2012, p. 25-27.51. Aryal KP, Berg A, Ogle BM: Uncultivated plants and livelihood support: a case study from the Chepang people of Nepal. Ethnobotanical Research Applications. 2009;7:409-422.

62. Sharma PK, Chauhan NS, Lal B. Studies on plant associated indigenous knowledge among the Malanis of Kullu district, Himachal Pradesh Indian. J Tradit Knowl. 2005:4(4):403-8.

63. Abbas Z, Khan SM, Abbasi AM, Pieroni A, Ullah Z, lqbal M, Ahmad Z. Ethnobotany of the Balti community, Tormik valley, Karakorum range, Balistan, Pakistan. J Ethnobiol Ethnomed. 2016;12:38.

64. Adnan M, Ullah I, Tariq A, Murad W, Azizullah A, Khan AL, Ali N. Ethnomedicine use in the war affected region of northwest Pakistan. Ethnobiol Ethnomed. 2014;10:16.

65. Kang Y, Luczaj L, Kang J, Wng F, Hou J, Guo Q. Wild food plants used by the Tibetans of Gongba valley (Zhouqu country, Gansu, China). J Ethnobiol Ethnomed. 2014;10:20

66. Thakur D, Sharma A, SKr U. Why they eat, what they eat: patterns of wild edible plants consumption in a tribal area of Western Himalaya. J Ethnobiol Ethnomed. 2017;13:70.

67. Liu D, Cheng H, Bussmann RW, Guo Z, Liu B, Long C. An ethnobotanical survey of edible fungi in Chuxiong City, Yunnan, China. J Ethnobiol Ethnomed. 2018;14:42.

68. Kumar M, Paul Y, Anand VK. An ethnobotanical study of medicinal plants used by the locals in Kishtwar, Jammu and Kashmir, India. Ethnobotanical Leaflets. 2009;13:1240-56.
69. Kumar PK, Singhal VK. Ethnobotany and ethnomedicinal use, chromosomal status and natural propagation of some plants of Lahaul-Spiti and adjoining hills. Journal of Botany. 2013; Hindawi Publishing Corporation.

70. Gupta A. Ethnobotanical studies on Gaddi tribe of Bharmour area of Himachal Pradesh. Ph.D. Thesis submitted in forestry to Dr. Yashwant Singh Parmar University of Horticulture and Forestry, Nauni, Solan, Himachal Pradesh. 2011.

71. EMA (European Medicines Agency), "Assessment report on Primulaveris L. and/or Primulaelatior (L.) Hill, flos," EMA/HMPC/136583/2012, 2012.

72. Awan MR, labal Z, Shah SM, Jamal Z, Jan G, Afzal M, Majid A, Gul A. Studies on traditional knowledge of economically important plants of Kaghan valley, Mansehra district, Pakistan. J Med Plant Res. 2011;5(16):3958-67.

73. Nautiyal M, Tiwari JK, Rawat DS. Exploration of some important fodder plants of Joshimath area of Chamoli district of Garhwal, Uttarakhand. Current Botany. 2017:8:144-9.

74. Singh T, Singh A, Dangwal LR. Impact of overgrazing and documentation of wild fodder plants used by Gujjar and Bakerwal tribes of district Rajouri (J\&K), India. Journal of Applied and Natural Science. 2016;8(2):804-11.

75. Kumar VSK. Prosopis cineraria and Ailanthus excelsa- fodder trees of Rajasthan. India International Tree Crops Journal. 1999;10:79-86.

76. Jagtap SD, Deokule SS, Bhosle SV. Some unique ethnomedicinal uses of plants used by the Korku tribe of Amravati district of Maharashtra, India. J Ethnopharmacol. 2006;107:463-9.

77. Akhtar N, Rashid A, Murad W, Bergmeier E. Diversity and use of ethnomedicinal plants in the region of Swat, North Pakistan. J Ethnobiol Ethnomed. 2013;9:25.

78. Ahmad H, Khan AM, Ghafoor S, Ali N. Ethnobotanical study of upper Siran. Journal of Herbs, Spices \& Medicinal Plants. 2009;15:86-97.

79. Martirosyan DM. Amaranth as a nutritional supplement for the modern diet. Amaranth Legacy, USA. 2001;14:2-4.

80. Bisht AK, Bhatt A, Rawal RS, Dhar U. Prioritization and conservation of Himalayan medicinal plants: Angelica glauca Edgew. as a case study. Ethnobotany Research \& Applications. 2006:11-23.

81. Mitra MP, Saumya D, Sanjita D, Kumar TM. Phyto-pharmacology of a Berberis aristata DC: a review. J Drug Delivery Ther. 2011;1:46-50.

82. Boesi A. Traditional knowledge of wild food plants in a few Tibetan communities. J Ethnobiol Ethnomed. 2014;10:75.

83. Aziz MA, Adnan M, Khan AH, Shahat AA, Al-Said MS, Ullah R. Traditional uses of medicinal plants practiced by the indigenous communities at Mohmand agency, FATA, Pakistan. J Ethnobiol Ethnomed. 2018;14:2.

84. Kala CP. The valley of flowers: myth and reality. Dehradun, India: International Book Distributor; 2004

85. Phondani PC. A study on prioritization and categorization of specific ailments in different high altitude tribal and non-tribal communities and their traditional plant based treatments in Central Himalaya. Ph. D Thesis. Gharwal, Uttarakhand: H.N.B. Gharwal Central University, Srinagar; 2010.

86. Sharma N. Conservation and utilization of medicinal and aromatic plants in Dhauladhar mountain range of Himachal Pradesh. Ph.D. Thesis. Dehradun, India: Forest Research Institute (Deemed University); 2017.

87. Khulbe K, Sati SC. Antibacterial activity of Boenninghausenia albiflora Reichb. (Rutaceae). Afr J Biotechnol. 2009;8(22):6346-8.

88. Rana MS, Rana SB, Samant SS. Extraction, utilization pattern and prioritization of fuel resources for conservation in Manali Wildlife Sanctuary, Northwestern Himalaya. Journal of Mountain Science. 2012;9:580-8.

89. Hong L, Guo Z, Huang K, Wei S, Bo L, Meng S, Long C. Ethnobotanical study on medicinal plants used by Maonan people in China. J Ethnobiol Ethnomed. 2015;11:32.

90. Samant SS, Singh M, Manohar L, Pant S. Diversity, distribution and prioritization of fodder species for conservation in Kullu District, Northwestern Himalaya, India. J Mt Sci. 2007;4(3):259-74.

91. Verma D, Singh G, Ram N. Carpinus viminea: a pioneer tree species of old landslide regions of Indian Himalaya. Curr Sci. 2009;97(9):1277-8.

92. Shah $\mathrm{R}$, Pande PC, Tiwari L. Traditional veterinary herbal medicines of western part of Almora district, Uttarakhand Himalaya. Indian J Tradit Knowl 2008;7(2):355-359

93. Negi VS, Maikhuri RK, Vashishtha DP. Traditional healthcare practices among the villages of Rawain valley, Uttarkashi, Uttarakhand, India. Indian J Tradit Knowl. 2011;10(3):533-7.

94. Ju Y, Zhuo J, Liu B, Long C. Eating from the wild: diversity of wild edible plants used by the Tibetans in Shangri-la region, Yunnan, China. J Ethnobiol Ethnomed. 2013;9:28. 
95. Carović-Stanko K, Grdiša M, Pintar J, Bedeković D, Ćustić MH, Satovic Z. Medicinal plants of the family Lamiaceae as functional foods - a review. Czech J Food Sci. 2016;34(5):377-90.

96. Tugume P, Kakudidi EK, Buyinza M, Namaalwa J, Kamatenesi M, Mucunguz $P$, Kalema J. Ethnobotanical survey of medicinal plant species used by communities around Mabira central Forest reserve, Uganda. J Ethnobiol Ethnomed. 2016;12:5.

97. Khan M, Kumar S, Hamal IA. Medicinal plants of Sewa river catchment area in the Northwest Himalaya and its implication for conservation. Ethnobotanical Leaflets. 2009;13:1113-39.

98. Sher H, Elyemeni M, Hussain K, Sher H. Ethnobotanical and economic observations of some plant resources from the northern parts of Pakistan. Ethnobot Res Appl. 2011:27-42.

99. PP Chauhan, Nigam A, K Santvan V. Ethnobotanical study of wild fruits in Pabbar Valley, District Shimla, Himachal Pradesh. Journal of Medicinal Plant Studies 2016:4(2):216-220.

100. Rahim IU, Maselli D, Rueff H, Wiesmann U. Indigenous fodder trees can increase grazing accessibility for landless and mobile pastoralists in northern Pakistan. Pastoralism. 2011;1:2.

101. Sharma P, Patti P, Agnihotry A. Ethnobotanical and ethnomedicinal uses of floristic diversity in Murari Devi and surrounding areas of Mandi in Himachal Pradesh, India. Pakistan Journal of Biological Sciences. 2013;16(10):451-68.

102. Prakash V. Studies on the ethnobotany of Shikari Devi sanctuary and Kamrunag hills, district Mandi. Shimla: Himachal Pardesh. Ph. D. thesis submitted to Himachal Pradesh University; 2014.

103. Sharma A. Studies on floristic diversity and prioritization of communities for conservation in Hirb and Shoja catchments district Kullu of Himachal Pradesh. Nainital: North Western Himalaya. Ph. D thesis submitted to Kumaun university; 2008.

104. Koelz WN. Notes on the ethnobotany of Lahul, a province of Punjab. Quart J Crude Drug Res. 1979;17:1-56.

105. Kletter C, Krichbaum M. Tibetan medicinal plants. Medpharm Scientific Publishers. 2001:241-6.

106. Pant B. Medicinal orchids and their uses: tissue culture a potential alternative for conservation. African J Plant Sci. 2013;7(10):448-67.

107. Kunwar RM, Bussmann RW. Ficus (Fig) species in Nepal: a review of diversity and indigenous uses. Lyonia. 2006;11(1):85-97.

109. Khan MA, Khan MA, Hussain M, Mujtaba G. An ethnobotanical inventory of Himalayan region Poonch valley Azad Kashmir (Pakistan). Ethnobot Res Appl. 2010;8:109-24.

108. Singh B, Sultan P, Hassan QP, Gairola S, Bedi YS. Ethnobotany, traditional knowledge, and diversity of wild edible plants and fungi: a case study in the Bandipora District of Kashmir Himalaya, India. Journal of Herbs, Spices \& Medicinal Plants. 2016;22(3):247-78.

110. Rana D, Masoodi HUR. Ethno-botanical survey for wild plants in fringe villages around Shimla Water Catchment Sanctuary, Himachal Pradesh, India. Journal of Applied and Natural Science. 2014;6(2):720-4

111. Rani S, Rana JC. Ethnobotanical uses of some plants of Bhattiyat block in district Chamba, Himachal Pradesh (Western Himalaya). Ethnobot Res Appl. 2014;12:407-14.

112. Polat R, Cakilcioglu U, Ulusan MD, Paksoy MY. Survey of wild food plants for human consumption in Elazig, Turkey. IndianJ Tradit Knowl. 2015;1(1):69-75

113. Malla B, Gauchan DP, Chhetri RB. An ethnobotanical study of medicinal plants used by ethnic people in Parbat district of western Nepal. J Ethnopharmacol. 2015;165:103-17.

114. Ghahremaninejad F, Joharchi M, Vitek E. New plant records for Khorassan province, Iran. Annalen des Naturhistorischen Museums in Wien B. 2005;106:255-93.

115. Khan SW, Khatoon S. Ethnobotanical studies on some useful herbs of Haramosh and Bugrote valleys in Gilgit, northern areas of Pakistan. Pak J Bot. 2008;40(1):43-58.

116. Kirtikar KR, Basu BD. Indian medicinal plants. 3rd ed. New Delhi: M.S. Periodical Experts; 1975.

117. Singh KK, Kumar K. Ethnobotanical wisdom of Gaddi Tribe in Western Himalaya: Bishen Singh and Mahendra Pal Singh; 2000.

118. Panda SK. Ethno-medicinal uses and screening of plants for antibacterial activity from Similipal Biosphere Reserve, Odisha, India. J Ethnopharmacol. 2014;151:158-75.

119. Wujisguleng W, Khasbagen K. An integrated assessment of wild vegetable resources in Inner Mongolian Autonomous Region, China. J Ethnobiol Ethnomed. 2010;6:34.
120. Ahmad K, Pieroni A. Folk knowledge of wild food plants among the tribal communities of Thakhte-Sulaiman hills, North-West Pakistan. J Ethnobiol Ethnomed. 2016;12:17.

121. Matin A, Khan MA, Ashraf M, Qureshi RA. Traditional use of herbs, shrubs, and trees of Shogran valley, Manshera, Pakistan. Pak J Biol Sci. 2001;4:1101-7.

122. Uniyal SK, Singh KN, Jamwal P, Lal B. Traditional use of medicinal plants among the tribal communities of Chhota Bhangal, Western Himalaya. J Ethnobiol Ethnomed. 2006;2:14.

123. Gairola S, Sharma J, Bedi YS. A cross-cultural analysis of Jammu, Kashmir, and Ladakh (India) medicinal plant use. J Ethnopharmacol. 2014;155:925-86.

124. Kayani S, Ahmad M, Sultana S, Shinwari ZK, Zafar M, Yaseen G, Hussain M, Bibi T. Ethnobotany of medicinal plants among the communities of Alpine and Sub-alpine regions of Pakistan. J Ethnopharmacol. 2015;164:186-202.

125. Samant SS, Pant S, Singh M, Manohar L, Singh A, Sharma A, Bhandari S. Medicinal plants in Himachal Pradesh, north western Himalaya, India. International Journal of Biodiversity Science and Management. 2007;3:234-51.

126. Gaur RD, Bhatt BP. Folk utilization of some pteridophytes of Deoprayag area in Gharwal Himalaya: India. Econ Bot. 1994;48(2):146-51.

127. Joshi AR, Joshi K. Plant diversity and ethnobotanical notes on tree species of Syabru Village, Langtang National Park, Nepal. Ethnobotanical Leaflets. 2009;13:651-64.

128. Bhattacharyya D. Rhododendron species and their uses with special reference to the Himalayas - a review. Assam University Journal of Science \& Technology: Biological and Environmental Sciences. 2011;7(1):161-7.

129. Rana PK, Kumar P, Singhal VK, Rana JC. Uses of local plant biodiversity among the tribal communities of Pangi Valley of district Chamba in cold desert Himalaya, India. In: The Scientific World Journal; 2014.

130. Sahu N, Arya KR. Ethnobotanical and ethnopharmacological activities of Artemisia nilagirica. Lyonia ovalifolia, Sarcococca saligna, and Taraxacum officinale. 2017;8(11):4818-25.

131. Akhtar N. Exploring patterns of phytodiversity, ethnobotany, plant geography and vegetation in the mountains of Miandam, Swat, Northern Pakistan. M. Phil. dissertation submitted to the Georg-August-University school of science (GAUSS), Gottingen. 2014.

132. Malik AK, Khuroo AA, Dar GH, Khan ZS. Ethnomedicinal uses of some plants in the Kashmir Himalaya. Indian J Tradit Knowl. 2011;10(2):362-6.

133. Thongam B, Konsam S, Handique AK. Assessment of wild leafy vegetables traditionally consumed by the ethnic communities of Manipur, northeast India. J Ethnobiol Ethnomed. 2016;12:9.

134. CAMP Report. Threatened medicinal plants of Himachal Pradesh, report of the 'CAMP' (Conservation Assessment \& Management Prioritisation) workshop held at Shimla on 1-4 December 2010, sponsored by Nationa Medicinal Plants Board, Government of India and organised by Himachal Pradesh Forest Department. 2010.

Ready to submit your research? Choose BMC and benefit from:

- fast, convenient online submission

- thorough peer review by experienced researchers in your field

- rapid publication on acceptance

- support for research data, including large and complex data types

- gold Open Access which fosters wider collaboration and increased citations

- maximum visibility for your research: over $100 \mathrm{M}$ website views per year

At $\mathrm{BMC}$, research is always in progress.

Learn more biomedcentral.com/submissions 